\title{
Medicinal chemistry of histone deacetylase inhibitors
}

\author{
Dusan Ruzic ${ }^{\#}$, Nemanja Djokovic $\#$, Katarina Nikolic and Zorica Vujic* \\ University of Belgrade - Faculty of Pharmacy, Department of Pharmaceutical \\ Chemistry, Vojvode Stepe 450, 11221 Belgrade, Serbia
}

*Corresponding author: Dr Zorica Vujic, E-mail: zvujic@pharmacy.bg.ac.rs

\# Authors contributed equally to the work

\begin{abstract}
Today, we are witnessing an explosion of scientific concepts in cancer chemotherapy. It has been considered for a long time that genetic instability in cancer should be treated with drugs that directly damage the DNA. Understanding the molecular basis of malignant diseases shed light on studying phenotypic plasticity. In the era of epigenetics, many efforts are being made to alter the aberrant homeostasis in cancer without modifying the DNA sequence. One such strategy is modulation of the lysine acetylome in human cancers. To remove the acetyl group from the histones, cells use the enzymes that are called histone deacetylases (HDACs). The disturbed equilibrium between acetylation and deacetylation on lysine residues of histones can be manipulated with histone deacetylase inhibitors (HDACi).

Throughout the review, an effort will be made to present the mechanistic basis of targeting the HDAC isoforms, discovered selective HDAC inhibitors, and their therapeutical implications and expectations in modern drug discovery.
\end{abstract}

Keywords: histone deacetylases, sirtuins, inhibitors, epigenetics, acetylome

doi.org/10.5937/arhfarm71-30618 


\section{Introduction}

The life of each cell is extremely turbulent. The control of discordant cell responses is mediated through communication between various biomolecules, starting from gene activation or repression, synthesis of mRNA and proteins. Diverse extracellular signals may induce changes in protein synthesis, cellular phenotype and integrity, metabolism and eventually cell survival. Protein biosynthesis in human cells is a costly process and not all cellular stimuli will induce de novo synthesis of proteins. Timewise, posttranslational modifications of certain proteins such as histones present effective control of cellular events via regulation of gene expression (1). Histones are major protein components of chromatin. Octamers consisting of two copies of core histones (H2A, $\mathrm{H} 2 \mathrm{~B}, \mathrm{H} 3$ and $\mathrm{H} 4)$ wrapped with DNA constitute functional units of chromatin nucleosomes. Being rich in lysine and arginine residues, histone's posttranslational modifications and consequent alteration of net charge of histones provide the basis for epigenetic regulation of gene expression, either by alteration of chromatin compaction or by the recruitment of specific proteins involved in transcriptional regulation $(2,3)$. Numerous histone marks are mapped in human cells and they are considered as epigenetic regulators of gene expression. Small endogenous molecules such as acetyl, methyl, benzoyl, phosphate, crotonyl, succinyl groups can be covalently attached to the amino acid residues (particularly lysine and arginine) $(4,5)$. The modified charged amino acid residues on histones may alter the DNA compaction, thus modifying the gene transcription (6).

The occurrence of histone marks is catalyzed by histone modifying enzymes, which can be classified into three major groups. Histone writers are the enzymes that catalyze the covalent attachment of the aforementioned small molecules, such as histone methyltransferases (HMTs), histone acetyltransferases (HATs). The second group are histone erasers, which modify the histones in the opposite way to writers, and these are histone demethylases (HDMs), histone deacetylases (HDACs). The third group of histone modifying enzymes is referred to as histone readers, which recognize histone modifications and promote the recruiting of numerous chromatin modifiers and transcription factors (7). The unique language of histone modifications (also known as a histone code) changes the function of genes without altering the DNA sequence.

The modification of histones by acetylation plays a key role in the epigenetic regulation of gene expression and is controlled by the balance between histone deacetylases (HDACs) and histone acetyltransferases (HAT). Histone deacetylases are the enzymes that remove the acetyl group from lysine residues in histone proteins on DNA and are widely studied epigenetic erasers due to their involvement in the pathophysiology of numerous malignancies (e.g. breast cancer, pancreatic cancer, hematological cancers) $(8,9)$. Their different tissue distribution, subcellular localization and diverse catalytic activities opened many avenues for drug discovery campaigns of selective HDAC inhibitors. It is worth mentioning that HDACs enzymes are classified in four different classes, according to their homology sequence $(7,8)$. The classes I, II and IV are zinc-dependent metalloenzymes, which use the $\mathrm{Zn}^{2+}$ ion for catalytic hydrolysis of 
acetyllysine moieties. Class I is comprised of four isoforms (HDAC1, HDAC2, HDAC3 and HDAC8) (12). Class II is divided in two subclasses - IIa and IIb. The isoforms belonging to subclass IIa are HDAC4, HDAC5, HDAC7 and HDAC9, whereas HDAC6 and HDAC10 belong to subclass IIb $(11,13)$. The third class of HDAC enzymes belongs to nicotinamide adenine dinucleotide $\left(\mathrm{NAD}^{+}\right)$-dependent deacetylases, commonly known as sirtuins, and it includes 7 isoforms (SIRT1-7) (14). The class IV HDAC is comprised of the unique HDAC11 isoform (15). It should be noted that HDACs are hydrolyzing other histone acyl- marks, such as N-terminal myristoyllysine and myristoylglycine, crotonyl, octanoyl etc. (16) which suggests their roles in metabolic homeostasis of the cell (17).

HDAC inhibitors (HDACis) are a class of compounds that increase the acetylation of lysine residues on histone proteins, as well as other proteins, by inhibiting the activity of HDACs enzymes. Histone deacetylase inhibitors induce growth arrest, differentiation and apoptosis of cancer cells ex vivo (18), as well as in vivo in tumor-bearing animal models (19), and are now undergoing clinical trials as anti-tumor agents. HDACis comprise structurally diverse compounds that are a group of targeted anticancer agents. The first of these new HDACi, vorinostat (suberoylanilide hydroxamic acid), has received Food and Drug Administration approval for treating patients with cutaneous T-cell lymphoma. In this review, we will outline the medicinal chemistry of selective Histone DeACetylase inhibitors (HDACi), targeting specific isoforms within classes, as well as the rationale for their use in certain therapeutic areas.

\section{Mechanism of acetyl group hydrolysis by HDACs}

The mechanism of acetyl group hydrolysis by classical $\mathrm{Zn}^{2+}$-dependent HDACs was first studied in bacterial histone deacetylase-like protein (20). There have been numerous mechanistic explanations proposed on the acetyl group cleavage from lysine side chains on histones. The catalytic site of HDACs is described as $14 \AA$ long tube-like pocket (Figure 1, sketched with brown tube) in which the catalytic $\mathrm{Zn}^{2+}$ ion (chelated with two conserved aspartates and one histidine) is located at the bottom of the channel (21). When $\mathrm{N}$-acetyllysine enters the catalytic pocket (stage [A]), the carbonyl oxygen coordinates $\mathrm{Zn}^{2+}$ ion, whereas the neighboring histidine deprotonates nucleophilic water. In the next stage [B], the generated oxyanion is chelated to the $\mathrm{Zn}^{2+}$ and the intermediate is hydrogen bonded to the conserved tyrosine. Finally, in the stage $[\mathbf{C}]$ the intermediate is decomposed to the acetyl anion and protonated lysine. The active site of HDACs is therefore composed of conserved histidine-aspartate dyads which regulated the $\mathrm{pH}$ of the microenvironment (22), tyrosine and $\mathrm{Zn}^{2+}$ ion, all of which are crucial for the HDAC catalytic activity. 


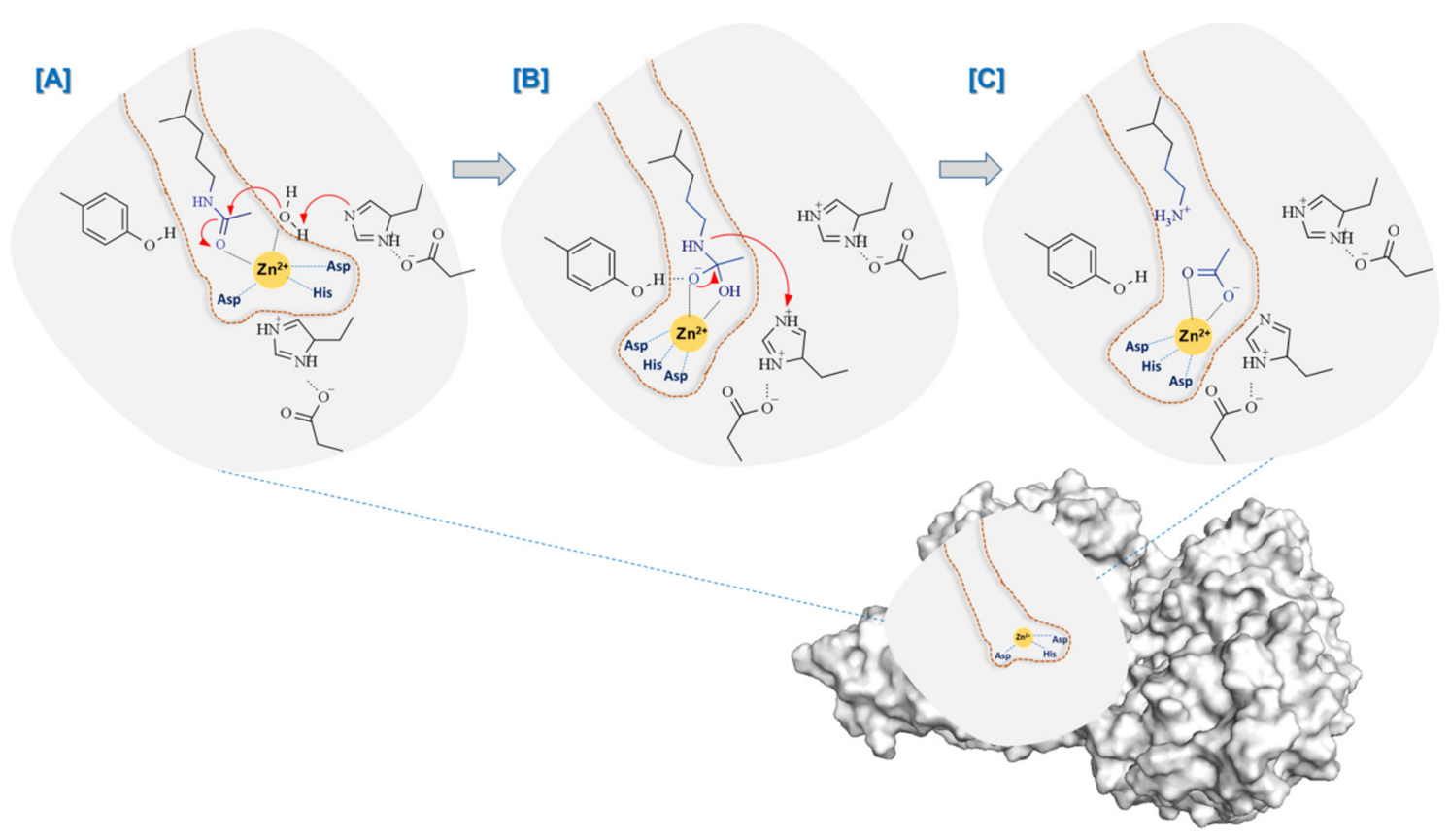

Figure 1. Metal-dependent hydrolysis of the acetylated lysine residue by histone deacetylase (hydrolytic model proposed from HDLP enzyme) adapted from the reference (22)

Slika 1. Metal-zavisna hidroliza acetilovanih lizina posredovana histon deacetilazama (pretpostavljeni model hidrolize na osnovu HDLP enzima) - prilagođeno na osnovu ref. (22)

Sirtuins contain a highly conserved catalytic core located at the interface of the two domains of enzyme structure - Rossmann fold domain and zinc-binding domain (Figure 2). In contrast to the other classes of HDACs, the mechanism of deacetylation of sirtuins (class III of HDACs) is $\mathrm{Zn}^{2+}$ independent and implies the presence of $\mathrm{NAD}^{+}$. Although $\mathrm{NAD}^{+}$is a redox-active metabolite, it is important to note that during deacetylation reaction catalyzed by sirtuins, there is no change of oxidation states of reactants. A simplified mechanism of the reaction is depicted in Figure 2. Once $\mathrm{NAD}^{+}$and $\mathrm{N}$-acetyllysine peptide are bound, the carbonyl oxygen of acetyl group attacks the anomeric position of ribose, cleaving nicotinamide and forming alkylimidate intermediate. After deprotonation of ribose at 2 ' $-\mathrm{OH}$ induced by the presence of conserved histidine residue as a general base, cyclic intermediate is formed which hydrolyze in the last step of reaction to produce 2'-O-acetyl-ADP-ribose. The formation of nicotinamide during catalysis is reversible, and nicotinamide itself is a pan-sirtuin inhibitor (23). 


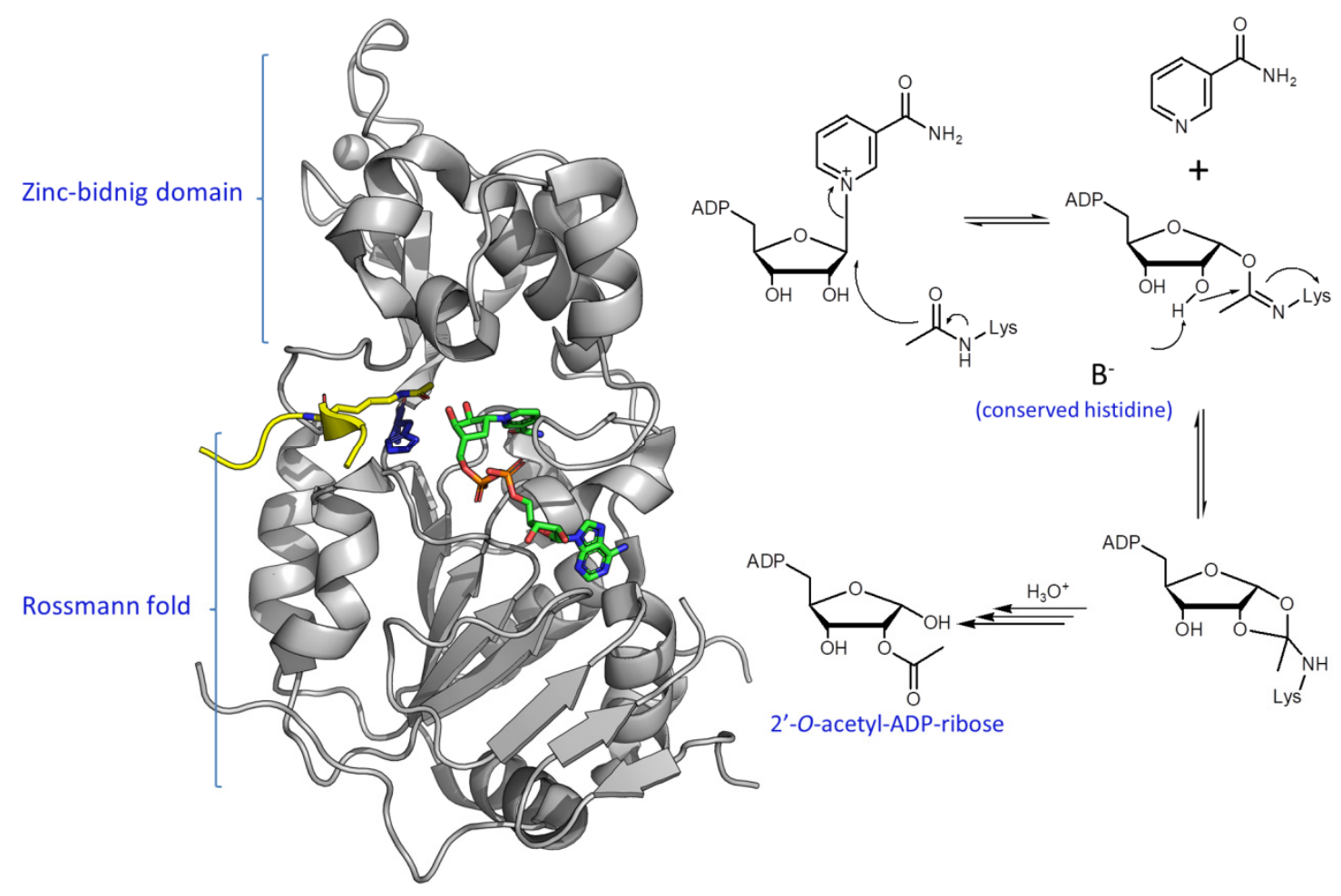

Figure 2. Representation of sirtuin structure (left) and mechanism of NAD+dependent hydrolysis of the acetylated lysine residue (right). Yellow cartoon represents peptide substrate, NAD+ is depicted in green sticks and conserved histidine residue in blue sticks

Slika 2. Prikaz strukture sirtuina (levo) i mehanizma NAD+-zavisne hidrolize acetilovanog lizina (desno). Žuto je obojen peptidni supstrat, struktura NAD+ je označena zelenom bojom i konzervirani histidin je prikazan plavom bojom

\section{HDAC inhibitors in drug discovery}

The story of the first discovered HDAC inhibitor (SAHA, suberoylanilide hydroxamic acid, Vorinostat) remains one of the textbook examples of how serendipity may lead to inspiring breakthroughs in medicinal chemistry. SAHA was discovered after observations that polar solvent DMSO (dimethylsulfoxide) may induce differentiation of murine erythroleukemia cells (MELC) to normoblasts which synthesize hemoglobin (24). Further structure-activity relationship studies led to the conclusion that bishydroxamate derivatives inhibit the growth of MELC and lead to induced erythroid differentiation. (Figure 3A). (25) 

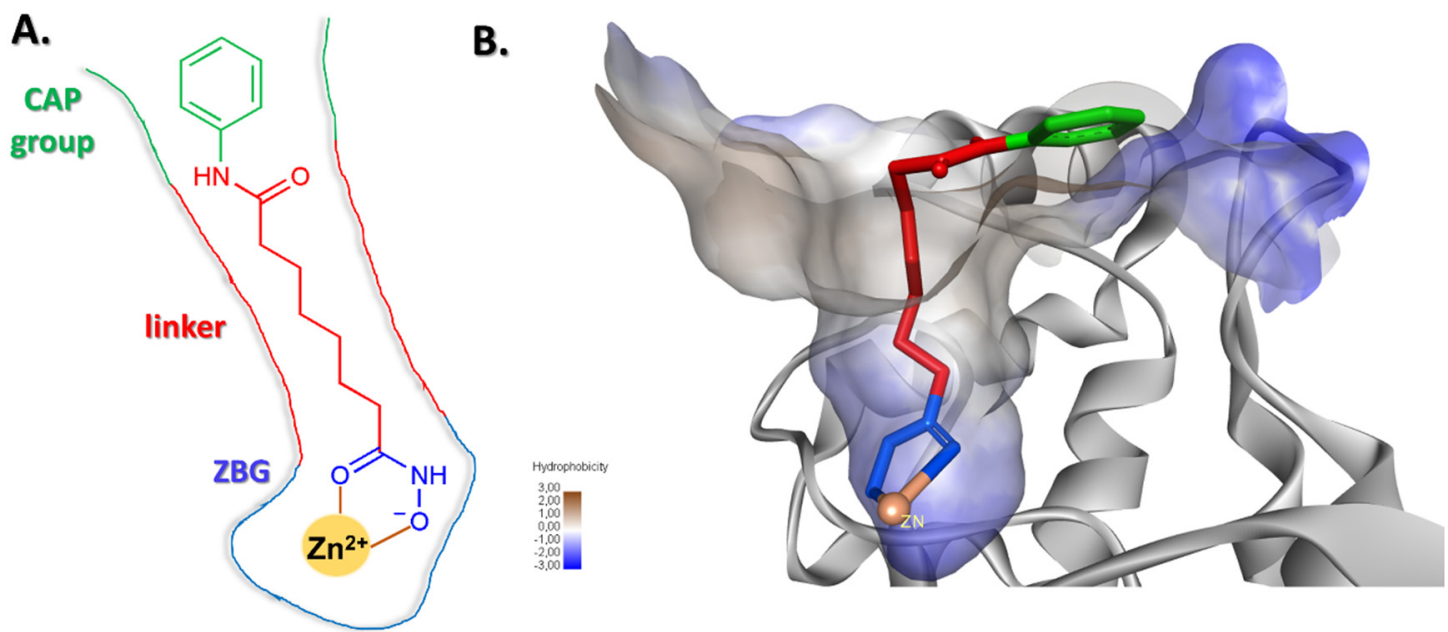

Figure 3. A. Two-dimensional presentation of HDAC inhibitor (SAHA) inside the binding pocket of HDAC (the amino acids which coordinate $\mathrm{Zn2}+$ ion at the bottom of the catalytic pocket are omitted for clarity); $B$. Threedimensional presentation of the SAHA anchored in the HDAC binding pocket

Slika 3. A. Dvodimenzionalni prikaz inhibitora Histon Deacetilaze (SAHA) unutar vezivnog džepa HDAC (aminokiseline koje koordiniraju Zn2+ jon na dnu džepa su izostavljene zbog jednostavnijeg prikaza); B. Trodimenzionalni prikaz strukture SAHA molekula usidrene u vezivno mesto HDAC enzima

From a mechanistic point of view, hydroxamic acid is a well-known zinc binding group (ZBG) which coordinates the catalytic zinc ion $\left(\mathrm{Zn}^{2+}\right)$ in many human enzymes. Hydroxamic acids are delivered to the bottom of the pocket via aliphatic or aromatic linkers, which mimic the lysine side chain (Figures 3B). The CAP (capping, surface recognition) group of the HDAC inhibitors interacts with the amino acid residues located at the entrance of the catalytic pocket and their presence/bulkiness are considered as important structural features for selective inhibition of certain HDACs.

First sirtuin inhibitors were discovered in 2001 and since then have represented an active area of research (26). Two decades of inhibitor development have resulted in a plethora of chemical scaffolds. Unfortunately, efforts have resulted in only one clinical candidate (27). Structural studies have indicated that many sirtuin inhibitors interact with $\mathrm{NAD}^{+}$-binding site (especially nicotinamide binding sub-pocket) and/or peptide substrate-binding site. High conservation between these two sites across the sirtuin family represents a significant challenge for the optimization of inhibitors' isoform selectivity. Besides selectivity, achieving low nanomolar potency and optimal pharmacokinetics is a long-standing challenge in sirtuin inhibitor drug discovery (27). Sirtuin inhibitors could be roughly divided into two classes: small molecule and mechanism-based inhibitors. Small molecule inhibitors non-covalently interact with amino acid residues from one or both binding sites in the sirtuin catalytic core. On the other hand, mechanism-based 
inhibitors are usually peptide or peptidomimetic molecules that are designed in such a way to represent substrates for sirtuin catalyzed deacylation. Upon the initiation of the reaction, mechanism-based inhibitors produce longer-lived (or stalled) intermediates that act as bisubstrate (interacting with both binding sites) inhibitory species. The general strategy for the design of mechanism-based inhibitors includes the introduction of warhead moieties such as thioamide or thiocarbamoyl moiety and some derivatives are reviewed in section $8(28)$.

\section{Selective class I HDAC inhibitors}

Class I of HDAC inhibitors are considered as prototypical epigenetic inhibitors. The nuclear localization of the class I HDACs makes them available for associations in transcriptional complexes (such as NuRD, Sin3A, CoREST) (29). These transcriptional complexes regulate cell survival and death, autophagy, changes in the cell morphology and cell differentiation. In recent years, drugging the HDAC1/HDAC2 isoforms has been validated for the reversal of the HIV latency (30).

The challenge in the development of specific class I HDAC inhibitors lies in the structural biology of these enzymes. The first two isoforms, HDAC1 and HDAC2 share the sequence homology of $86 \%$ (31). Owing to this, many reported class I HDAC inhibitors show non-selective profiles. The examples of the class I HDAC inhibitors are presented in Figure 4. Compound 1 (Entinostat) was discovered as a class I HDAC inhibitor, with an inhibitory profile against HDAC1-3 isoforms and low potency to HDAC8. Further crystallography studies with class I HDACs shed light on an additional foot pocket close to the catalytic site. The exploitation of the additional hydrophobic pocket by introducing the aromatic rings in position 5 of 2-aminoanilides (compound 2 , Figure 4) improved the selectivity towards HDAC1/HDAC2 isoforms. Merck \& Co employed a parallel medicinal chemistry strategy to synthesize, screen and identify selective HDAC3 inhibitors. They identified compound 3 in which the substitution of 2amino group with 2-methylthio group within ZBG clearly demonstrates selective HDAC3 inhibitory profile (32).

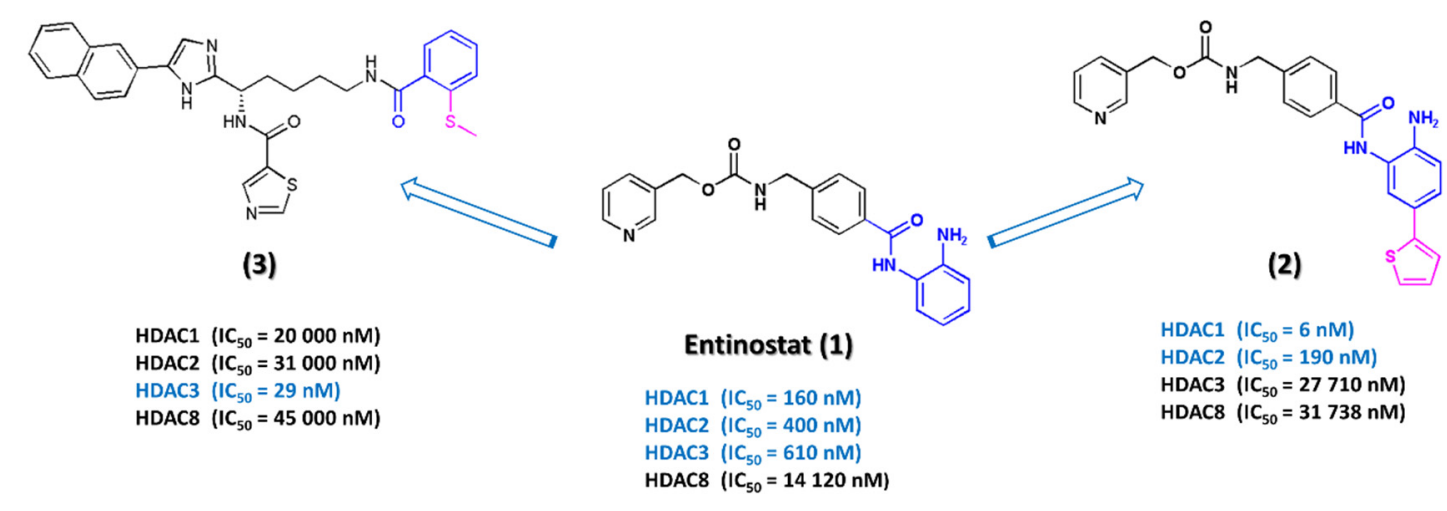

Figure 4. Chemical structures of class I HDAC inhibitors

Slika 4. Hemijske strukture inhibitora HDAC I klase 
It is interesting to mention that the HDAC8 isoform is the most studied isoform from a crystallographic point of view. The Protein Data Bank website (https://www.rcsb.org/) has more than 90 deposited structures of HDAC8 in complex with diverse inhibitors. HDAC8 has several features distinct from other isoforms among class I HDACs. The most important structural feature is the flexible surface loop L1 at the N-terminal portion (amino acids from 30 to 36) (33). Moreover, the leucine amino acid residues within the catalytic pocket of HDAC1-3 are substituted by tryptophan in HDAC8, making the $\mathrm{Zn}^{2+}$ ion at the bottom of the pocket hardly targeted by voluminous 2 -aminoanilides $(26,27)$. The outer rim of the catalytic cavity is shaped with F152, F208 and M274, where the F152 residue acts as a gatekeeper. Hence, the most common scaffold used in the design of selective HDAC8 inhibitors is meta-substituted phenylhydroxamate (36). Several selective HDAC8 inhibitors are presented in Figure 5. Interested readers are referred to references (37-42) where the most recent selective HDAC8 inhibitors are disclosed. Compound 4 (PCI-34051) is developed as a nanomolar HDAC8 inhibitor $\left(\mathrm{IC}_{50}=10 \mathrm{nM}\right)$ with more than 200 times lower affinities to other HDACs (43). An interesting synthetic approach by the use of $\mathrm{Cu}$ (I)-catalyzed azide-alkyne cycloaddition (known as click chemistry) employed by T. Suzuki et al. (44) developed selective HDAC8 nanomolar inhibitor 5 which inhibits the growth of the neuroblastoma cells (Figure 5).

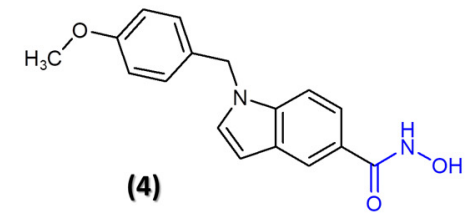

HDAC1 $\left(I C_{50}=4000 \mathrm{nM}\right)$

HDAC2 $\left(\mathrm{IC}_{50}>50 \mu \mathrm{M}\right)$

HDAC3 $\left(\mathrm{IC}_{50}>\mathbf{5 0} \mu \mathrm{M}\right)$

HDAC6 $\left(I C_{50}=2900 \mathrm{nM}\right)$

HDAC10 $\left(I C_{50}=13000 \mathrm{nM}\right)$

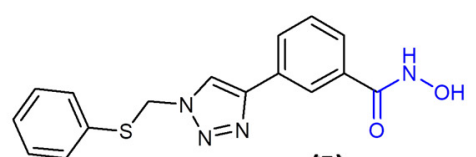

(5)

HDAC1 $\left(\mathrm{IC}_{50}=38000 \mathrm{nM}\right)$ HDAC2 $\left(\mathrm{IC}_{50}>100 \mu \mathrm{M}\right)$ HDAC6 $\left(I C_{50}=2400 \mathrm{nM}\right)$ HDAC8 $\left(\mathrm{IC}_{50}=70 \mathrm{nM}\right)$

Figure 5. Chemical structures of selective HDAC8 inhibitors

Slika 5. Hemijske strukture selektivnih inhibitora HDAC8 izoforme

\section{Selective class IIa HDAC inhibitors}

The class IIa HDACs is known to shuttle between the nucleus and the cytoplasm. They exert lower deacetylase activities than class I HDACs, due to the replacement of catalytic tyrosine with histidine (Y976H) (45). The endogenous substrates for these isoforms have recently been disclosed, such as myosin heavy chain (MyHC) isoforms, peroxisome proliferator-activated receptor gamma co-activator 1alpha (PGC-1 $\alpha$ ), and heat shock cognate $71 \mathrm{kDa}$ protein (Hsc70) (46). Nowadays, there are validated data that support targeting class IIa HDACs in diabetes (47), neurological diseases (48) and heart failure (49). 
In 2013, Lobera et al. (50) ran a high-throughput screening of the two-million GlaxoSmithKline's library of compounds and discovered inhibitors with trifluoromethyloxadiazolyl moiety as a nonchelating ZBG (compound 6, Figure 6). It is demonstrated that one fluorine and oxygen from the 1,2,4-oxadiazole interact with $\mathrm{Zn}^{2+}$ ion via weak electrostatic interactions. By the end of 2019, Novartis had published highly potent class IIa HDACi (compound 7) which presents a valuable chemical tool for studying skeletal muscle atrophy and sarcopenia (46).

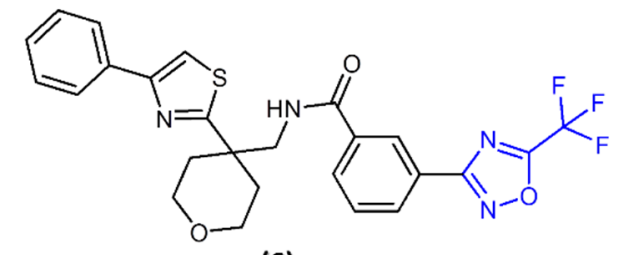

(6)

HDAC4 $\left(\mathrm{IC}_{50}=126 \mathrm{nM}\right)$ HDAC5 $\left(\left(\mathrm{C}_{50}=80 \mathrm{nM}\right)\right.$ HDAC7 $\left(I C_{50}=36 \mathrm{nM}\right)$ HDAC9 $\left(I C_{50}=19 \mathrm{nM}\right)$ HDAC6 $\left(\mathrm{IC}_{50}=7039 \mathrm{nM}\right)$ HDAC1 $\left(\right.$ I $\left.\mathrm{C}_{50}>23 \mathrm{nM}\right)$ HDAC2 $\left(\right.$ I $\left.C_{50}>19 \mathrm{nM}\right)$ HDAC8 $\left(I C_{50}=3570 \mathrm{nM}\right)$

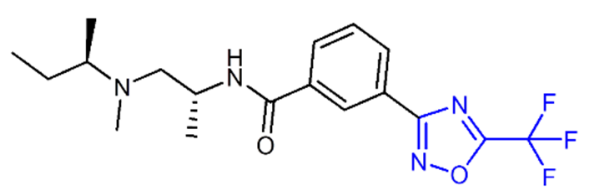

(7)

Figure 6. Chemical structures of class IIa HDAC inhibitors

Slika 6. Hemijske strukture inhibitora HDAC IIa klase

\section{Selective class IIb HDAC inhibitors}

Histone deacetylases 6 and 10 differ from other HDAC classes for diverse reasons. Both isoforms contain two domains, HDAC6 has two catalytic deacetylase domains, however, HDAC10 has one deacetylase domain and another one deficient in amino acids required for deacetylase activity (51). Furthermore, HDAC6 and HDAC10 isoforms are mainly located in the cytoplasm. HDAC6 controls the acetylation status of alpha-tubulin and/or microtubules (52) and HDAC10 is deacetylating polyamines, such as $\mathrm{N}^{8}$-acetylspermidine (51). HDAC6 is also referred to as tubulin-deacetylase (TDAC), whereas HDAC10 is considered as polyamine deacetylase (PDAC). The architecture of these isoforms is well-studied by Christianson, whose crystallography studies on zebrafish models (PDB codes HDAC6: 5EDU and HDAC10: 5TD7) $(53,54)$ expanded our understanding of the protein structure, function and pharmacomodulation of class IIb HDACs. Studies with peptide constructs revealed that the second catalytic domain (CD2) of HDAC6 is responsible for the tubulin-deacetylase activity and it is considered as a valid target for computer-aided drug discovery (CADD) campaigns.

It is proposed that every pharmacophoric feature (chemistry of the ZBG, linker and CAP group) contributes to the selectivity of the HDAC6 inhibitors (55). Computational $(56,57)$ and experimental $(44,45)$ studies published in our group show that both the alkylhydroxamates $(\mathbf{8}, \mathbf{9})$ and phenylhydroxamates (10) may inhibit the HDAC6 isoform selectively (Figure 7). Apart from hydroxamic acid derivatives, 3-hydroxypyridin-2- 
thiones (11) are reported as ZBG which specifically inhibits the HDAC6 isoform (60). Compounds with significantly voluminous CAP group, such as tubacin (9), were identified as valuable chemical tools to study HDAC6 inhibition. Surprisingly, capless HDAC6 inhibitors (Figure 7) demonstrated nanomolar inhibitory profiles, illustrating the importance of the entropic contribution to HDAC6-inhibitor binding selectivity (61). These fragment-like molecules $(\mathbf{1 2}, \mathbf{1 3})$ inhibit the HDAC8 isoform in submicromolar concentrations, which should be regarded as an important task while designing novel selective HDAC6 inhibitors.

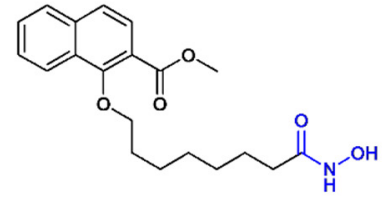

(8)

HDAC6 $\left(\mathrm{IC}_{50}=95 \mathrm{nM}\right)$ HDAC1 $\left(\right.$ IC $\left._{50}=3500 \mathrm{nM}\right)$ HDAC2 $\left(\right.$ IC $\left.\mathrm{C}_{50}=3400 \mathrm{nM}\right)$ HDAC3 $\left(I C_{50}=1000 \mathrm{nM}\right)$ HDAC8 $\left(\mathrm{IC}_{50}=1600 \mathrm{nM}\right)$<smiles>CCCCN(Cc1ccc(C(=O)NO)cc1)C(=O)Nc1ccccc1</smiles>

(10)

HDAC6 $\left(\mathrm{IC}_{50}=5.02 \mathrm{nM}\right)$ HDAC1 $\left(I_{50}=3020 \mathrm{nM}\right)$

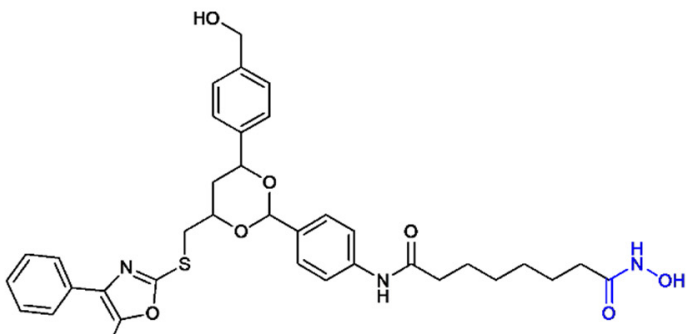

(9)

HDAC6 $\left(I C_{50}=4 \mathrm{nM}\right)$ HDAC1 $\left(I C_{50}=193 \mathrm{nM}\right)$

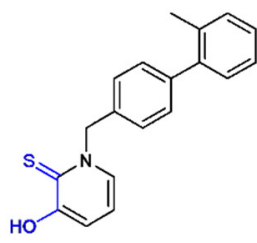

(11)

HDAC6 $\left(\mathrm{IC}_{50}=306 \mathrm{nM}\right)$ HDAC1 $\left(I_{50}=3105 \mathrm{nM}\right)$

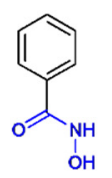

(12)

HDAC6 $\left(\mathrm{IC}_{50}=115 \mathrm{nM}\right)$ HDAC8 $\left(I C_{50}=1900 \mathrm{nM}\right)$

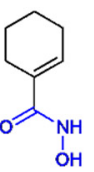

(13)

HDAC6 $\left(\mathrm{IC}_{50}=12 \mathrm{nM}\right)$ HDAC8 $\left(\mathrm{IC}_{50}=430 \mathrm{nM}\right)$

Figure 7. Chemical structures of selective HDAC6 inhibitors

Slika 7. Hemijske stukture selektivnih inhibitora HDAC6

Polyamine deacetylase (HDAC10) was studied in detail by Miller et all (62). This group found that tubastatin A (compound 15, previously shown as a selective HDAC6 inhibitor, (63)) was a more potent HDAC10 inhibitor, due to the presence of basic nitrogen in the CAP group. This tertiary nitrogen establishes a salt bridge with the gatekeeping residue (Glu272) which is required for polyamine deacetylase activity. When tetrahydro- $\beta$-carboline scaffold is replaced with the 3,4-dihydropyran (compound 16), the compounds show selectivity towards the HDAC6 isoform (Figure 8). $\mathrm{N}^{8}$-acetylspermidine derivatives in complex with zebrafish HDAC10 were studied by Xray crystallography (64) and it was found that the most potent compound is thioacetate prodrug $\mathbf{1 6}$ which is hydrolyzed to give thiolate active compound, as an HDAC10 inhibitor (17, Figure 8). 


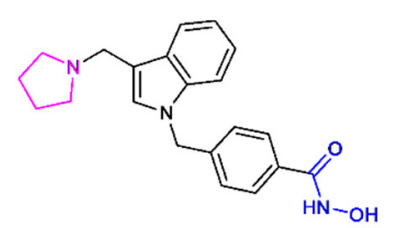

(14)

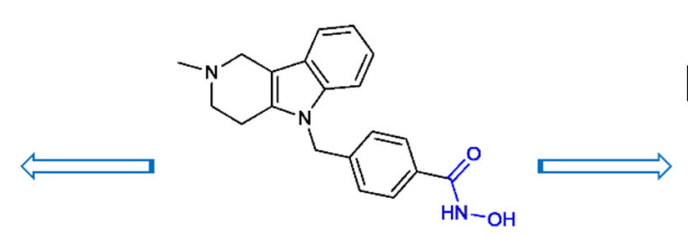

(15)

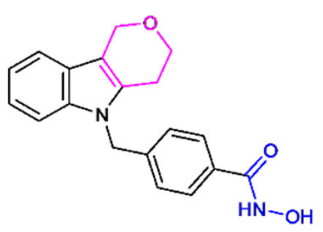

(16)

HDAC6 $\left(\mathrm{IC}_{50}=19.95 \mathrm{nM}\right)$ HDAC10 $\left(\mathrm{IC}_{50}=1000 \mathrm{nM}\right)$

HDAC6 $\left(I C_{50}=3020 \mathrm{nM}\right)$ HDAC10 $\left(\right.$ IC $\left._{50}=4 \mathrm{nM}\right)$

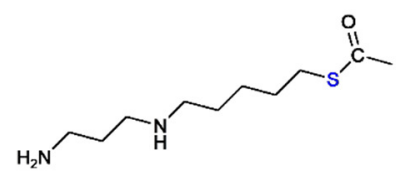

(16) - prodrug
HDAC6 $\left(\mathrm{IC}_{50}=100 \mathrm{nM}\right)$ HDAC10 $\left(I \mathrm{C}_{50}=13 \mathrm{nM}\right)$

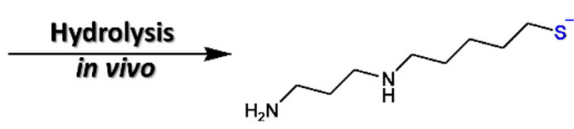

(17) - active HDAC10 inhibitor

HDAC10 $\left(\mathrm{IC}_{50}=30 \mathrm{nM}\right)$

Figure 8. Chemical structures of selective HDAC10 inhibitors (compounds 14, 15 and 17)

Slika 8. Hemijske strukture selektivnih inhibitora HDAC10 (jedinjenja 14, 15 i 17)

\section{Selective class IV HDAC inhibitors}

The single representative in class IV, HDAC11, is the smallest isoform among metal-dependent HDACs. It has recently been shown that HDAC11 has a more efficient glycine demyristoylation activity than deacetylase activity. Its implication in the IFNsignaling pathway has become advantageous for the drug design of novel antiviral and anticancer compounds $(51,52)$.

There is a small number of available selective HDAC11 inhibitors, some of which are presented in Figure 9. It is assumed that the natural product garcinol $\mathbf{1 8}$ could chelate $\mathrm{Zn}^{2+}$ ion via the enol form of the $\beta$-diketone moiety or with the catechol moiety (67). An interesting finding was recently published by Chellappan and colleagues, demonstrating that selective HDAC11 inhibitors (compound 19) are potent in preventing the growth of adenocarcinoma stem cells when co-cultured with cancer associated fibroblasts (CAFs) (68). To conclude, compounds $\mathbf{1 9}$ and $\mathbf{2 0}$ are potent lysine demyristoylases (69), whereas compound $\mathbf{2 0}$ is pure and cell-permeable selective HDAC11 inhibitor. 


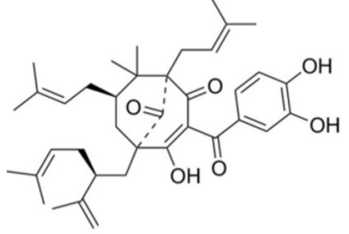

(18) - Garcinol

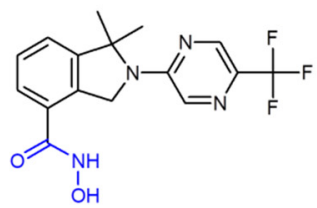

(19)

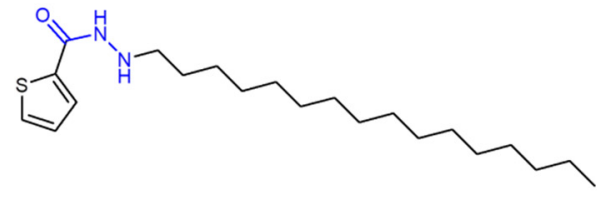

(20)

HDAC11 $\left(\mathrm{IC}_{50} \sim 5 \mu \mathrm{M}\right)$ HDAC8 $\left(\mathrm{IC}_{50}=9200 \mathrm{nM}\right)$

Figure 9. Chemical structures of selective HDAC11 inhibitors

Slika 9. Hemijske strukture selektivnih inhibitora HDAC11

\section{Selective class III HDAC inhibitors (sirtuins)}

Due to their involvement in many biological processes in the human organism, seven members of the sirtuins family are considered as potential targets in the treatment of several diseases, including cancer, neurodegenerative and cardiovascular diseases (70). In this section, some of the most important achievements and latest breakthroughs in the field of the medicinal chemistry of sirtuin inhibitors are presented.

\section{Non-selective sirtuin inhibitors}

According to the sequence alignment of seven sirtuins, the most conserved domains are recorded between SIRT1-3 isoforms, making it particularly difficult to achieve the ultimate goal of selectivity (71). Non-selective sirtuin inhibitors presented in this section of the review are depicted in Figure 10. Back in the early 2000s, using phenotypic yeastbased high-throughput screenings, two groups independently discovered the first SIRT inhibitors - splitomicin (compound 21) and sirtinol (compound 22) (26,72). Both compounds were based on a $\beta$-naphtol scaffold. Considering the sensitivity on hydrolysis of the $\delta$-lactone moiety in splitomicin, further efforts resulted in cambinol, 23, and its derivatives as a well-suited compound for in vitro studies. Cambinol was shown to be well tolerated and to inhibit the growth of Burkitt lymphoma xenografts in mice (73). Salermid, 24, reverse amide of sirtinol, 22, was designed utilizing CADD techniques (74). Another group of non-selective inhibitors identified through computational approaches, specifically virtual screening, was the thiobarbiturate group of inhibitors. Among this group, indole derivative, compound 25, exhibited slight selectivity towards SIRT1 (75).

Tenovins are another class of non-selective SIRT1/2 inhibitors, discovered through cell-based screening aimed at discovering tumor suppressor p53 activators. Among tenovins, Tenovin-6, 26, is now commonly used in in vitro studies due to favorable solubility (76). The extensive anticancer activity of tenovin-6 has been thoughtfully studied in the last years (77). Pseudopeptidic mechanism-based inhibitors based on thiourea, 27, were reported as well (78). Some of the most potent small molecule SIRT1/2/3 inhibitors reported so far were thieno[3,2-d]pyrimidine-6-carboxmamides (e.g. compound 28). 
<smiles>O=C1CCc2c(ccc3ccccc23)O1</smiles>

\section{(21) Splitomicin}

SIRT1 $\left(\right.$ IC $\left._{50}=96.2 \mu \mathrm{M}\right)$

SIRT2 $\left(I_{50}=112.96 \mu \mathrm{M}\right)$<smiles>CC(C(=O)Nc1cccc(/N=C/c2c(O)ccc3ccccc23)c1)c1ccccc1</smiles>

(24) Salermide

SIRT1 $\left(I_{50}=40.3-76 \mu \mathrm{M}\right.$ SIRT2 $\left(\right.$ IC $\left._{50}=25-45 \mu \mathrm{M}\right)$<smiles>COc1ccc2[nH]cc(CCNC(=O)C(CCCCNC(C)=S)NC(=O)OCc3ccccc3)c2c1</smiles><smiles>CC(NC(=O)c1ccccc1/N=C/c1c(O)ccc2ccccc12)c1ccccc1</smiles>

(22) Sirtinol

SIRT1 $\left(\mathrm{IC}_{50}=38-123 \mu \mathrm{M}\right)$

SIRT2 $\left(\right.$ IC $\left._{50}=45,1-103.4 \mu \mathrm{M}\right)$

SIRT3 $\left(I_{50}=24 \% @ 50 \mu \mathrm{M}\right)$<smiles>O=C1NC(=S)NC(=O)C1=Cc1c[nH]c2ccccc12</smiles>

\section{(25)}

SIRT1 $\left(\mathrm{IC}_{50}=5.9 \mu \mathrm{M}\right)$

SIRT2 $\left(\mathrm{IC}_{50}=20.3 \mu \mathrm{M}\right)$

SIRT3 $\left(I_{50}=16 \% @ 50 \mu \mathrm{M}\right)$

SIRT5 $\left(I_{50}=46.5 \mu \mathrm{M}\right)$

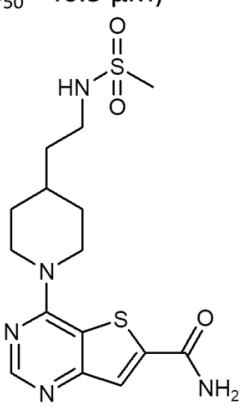<smiles>O=C1NC(=S)NC(c2ccccc2)C1Cc1c(O)ccc2ccccc12</smiles>

(23) Cambinol

SIRT1 $\left(\mathrm{IC}_{50}=40.7-56 \mu \mathrm{M}\right)$

SIRT2 $\left(\right.$ IC $\left._{50}=45,86-59 \mu \mathrm{M}\right)$

SIRT3 $\left(I_{50}=16 \% @ 50 \mu \mathrm{M}\right)$<smiles>CN(C)CCCCC(=O)Nc1ccc(NC(=S)NC(=O)c2ccc(C(C)(C)C)cc2)cc1</smiles>

(26) Tenovin-6

SIRT1 $\left(\mathrm{IC}_{50}=21-42.1 \mu \mathrm{M}\right)$ SIRT2 $\left(I_{50}=10-29.73 \mu \mathrm{M}\right)$ SIRT3 $\left(I_{50}=82.65 \mu \mathrm{M}\right)$<smiles>COc1cc(O)c(C(=O)/C=C/c2ccc(O)cc2)cc1Oc1ccc(C(=O)/C=C/c2ccc(O)cc2O)c(O)c1</smiles>

\section{(27)}

SIRT1 $\left(\mathrm{IC}_{50}=5.98 \mu \mathrm{M}\right)$ SIRT2 $\left(\mathrm{IC}_{50}=25.8 \mu \mathrm{M}\right)$ SIRT3 $\left(\right.$ IC $\left._{50}=29.4 \mu \mathrm{M}\right)$

\section{(28)}

SIRT1 $\left(I_{50}=0.004 \mu \mathrm{M}\right)$ SIRT2 $\left(I_{50}=0.001 \mu \mathrm{M}\right)$ SIRT3 $\left(I_{50}=0.007 \mu \mathrm{M}\right)$

\section{(29) Rhuschalcone I}

\section{analogue}

SIRT1 $\left(\mathrm{IC}_{50}=40.8 \mu \mathrm{M}\right)$

SIRT2 $\left(I_{50}=44.8 \mu \mathrm{M}\right)$

SIRT3 (Inh=23\%@50 $\mu \mathrm{M})$<smiles>CC(C)=CCc1c(O)cc2oc3cc(C)c(O)c(CC=C(C)C)c3c(=O)c2c1O</smiles>

(30) $\boldsymbol{\gamma}$-mangostin

SIRT1 $\left(\mathrm{IC}_{50}=22.4 \mu \mathrm{M}\right)$ SIRT2 $\left(\mathrm{IC}_{50}=3.8 \mu \mathrm{M}\right)$ SIRT3 $\left(I_{50}=26.8 \mu \mathrm{M}\right)$

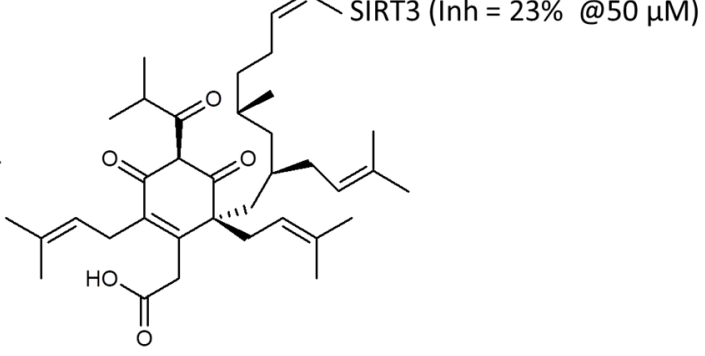

(31) Aristoforin SIRT1 IC $50=7 \mu \mathrm{M}$ SIRT2 IC $50=21 \mu \mathrm{M}$

Figure 10. Chemical structures of non-selective sirtuin inhibitors.

Slika 10. Hemijske strukture neselektivnih inhibitora sirtuina 
Crystallographic analysis indicated that common carboxamide of $\mathbf{2 8}$ binds in the nicotinamide portion of the $\mathrm{NAD}^{+}$-binding site and the aliphatic portions of the inhibitors extend through the substrate channel (79).

As possible sirtuin inhibitors, natural products draw significant attention (reviewed elsewhere) (79). Bichalcones isolated from medicinal plant Rhus pyroides (e.g. rhuschalcone I analogue, 29), were recently shown to be SIRT1/2 inhibitors (80). Xanthonoids isolated from Garcinia mangostana (e.g. $\gamma$-mangostin, 30) were recently discovered to be potent SIRT1-3 inhibitors (81). Phloroglucinol derivative extracted from Hypericum perforatum - hyperforin and its synthetic derivative aristoforin, $\mathbf{3 1}$ were proven to be SIRT1/SIRT2 inhibitors (82).

\section{Selective SIRT1 inhibitors}

The only sirtuin inhibitor that reached clinical studies was the moderately selective SIRT1 inhibitor EX-527, also known as Selisistat 32 (Figure 11). Namely, SIRT1 inhibitor EX-527 was tested in a clinical trial for Huntington's disease (83). This clinical trial was dropped after phase II, even though EX-527 was found to be safe and well tolerated. EX-527 was discovered in high-throughput screening on SIRT1 and it was described as a low molecular weight, cell-permeable, orally bioavailable, and metabolically stable inhibitor (84). The very first reported co-crystal structure of SIRT1 was in a complex with EX-527, which helped to decipher the structure-activity relationship of EX-527 and its derivatives. Indole moiety of EX-527 interacts with substrate binding site, while amide moiety is responsible for displacing nicotinamide of $\mathrm{NAD}^{+}$and it is crucial for the inhibitory activity of this group of inhibitors (85). Indole appears to be one of the privileged scaffolds in selective SIRT1 inhibitors design $(25,27)$ since the presence of this heterocycle in the structure of SIRT inhibitors shifts selectivity towards SIRT1 $(27,86)$. 

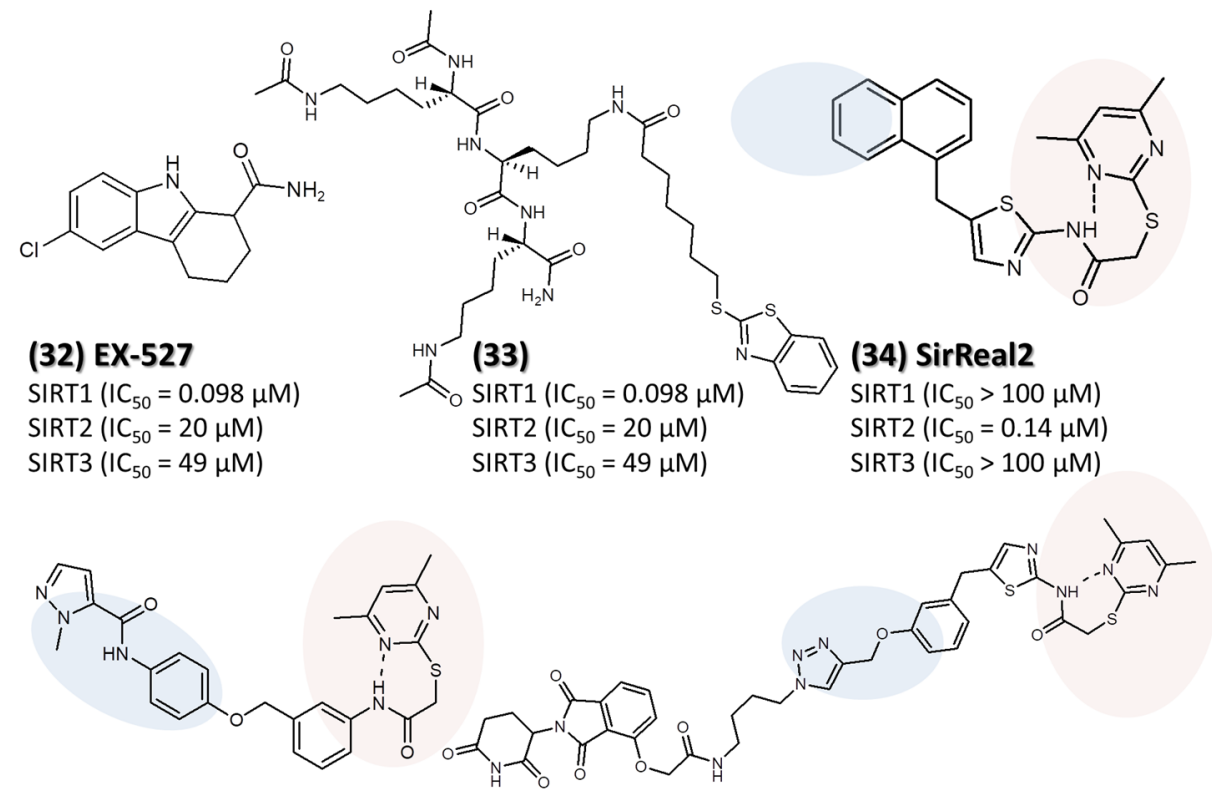

(35)

SIRT1 $\left(\mathrm{IC}_{50}>100 \mu \mathrm{M}\right)$

SIRT2 $\left(I_{50}=0.815 \mu \mathrm{M}\right)$

SIRT3 $\left(I_{50}>100 \mu \mathrm{M}\right)$

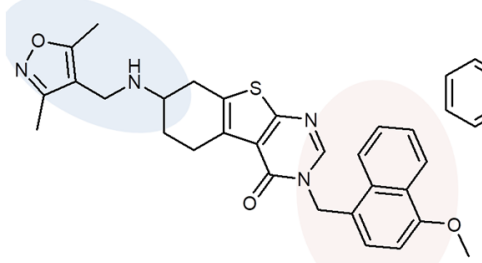

(37)

SIRT1 $\left(\mathrm{C}_{50}>100 \mu \mathrm{M}\right)$

$\operatorname{SIRT2}\left(\mathrm{IC}_{50}=0.58 \mu \mathrm{M}\right)$

SIRT3 $\left(\mathrm{IC}_{50}>100 \mu \mathrm{M}\right)$

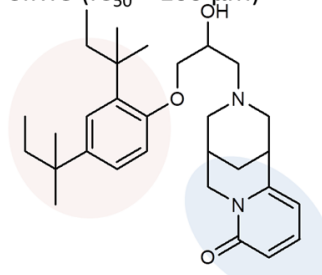

(40)

SIRT1 $\left(\mathrm{IC}_{50}>100 \mu \mathrm{M}\right)$

SIRT2 $\left(I_{50}=0.46 \mu \mathrm{M}\right)$

SIRT3 $\left(\mathrm{IC}_{50}>100 \mu \mathrm{M}\right)$
(36)

SIRT1 $\left(\mathrm{IC}_{50}>100 \mu \mathrm{M}\right)$

$\operatorname{SIRT2}\left(\mathrm{IC}_{50}=0.25 \mu \mathrm{M}\right)$

SIRT3 $\left(\right.$ IC $\left._{50}>100 \mu \mathrm{M}\right)$

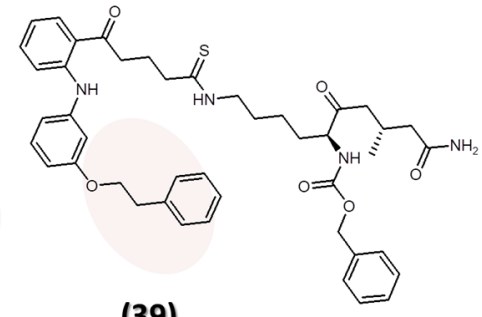

(39)

(38)

SIRT1 $\left(\mathrm{IC}_{50}>300 \mu \mathrm{M}\right)$

SIRT2 $\left(I C_{50}=1 \mu \mathrm{M}\right)$

SIRT3 $\left(I C_{50}>300 \mu \mathrm{M}\right)$

SIRT1 $\left(\mathrm{IC}_{50}=1.56 \mu \mathrm{M}\right)$

SIRT2 $\left(\right.$ IC $\left._{50}=0.055 \mu \mathrm{M}\right)$

SIRT3 $\left(I_{50}=9.49 \mu \mathrm{M}\right)$<smiles>CCCCCCCCCCC(=S)NCCCCC(NC(=O)OCc1ccccc1)C(=O)Nc1ccccc1</smiles>

(41)

SIRT1 $\left(\mathrm{IC}_{50}=98 \mu \mathrm{M}\right)$

SIRT2 $\left(I_{50}=0.028 \mu \mathrm{M}\right)$

SIRT3 $\left(\mathrm{IC}_{50}>200 \mu \mathrm{M}\right)$

$\mathrm{IC}_{50}($ SIRT5-7) $>200 \mu \mathrm{M}$

Figure 11. Chemical structures of selective SIRT1 and SIRT2 inhibitors. Blue fields represent moieties interacting with substrate binding site, while sand color fields depict moieties interacting with "selectivity pocket" of SIRT2

Slika 11. Hemijske strukture selektivnih SIRT1 i SIRT2 inhibitora. Plavo su Označene Grupe koje intereaguju sa vezivnim mestom za supstrat, dok su bojom peska označene grupe koje intereaguju sa „selektivnim džepom” u okviru SIRT2 izoforme 
In the group of mechanism-based inhibitors, one example is compound $\mathbf{3 3}$. Although this inhibitor should not be strictly considered as a mechanism-based inhibitor, it represents the most selective SIRT1 inhibitor reported so far in this group of sirtuin inhibitors (87).

\section{Selective SIRT2 inhibitors}

The latest breakthrough in the field of medicinal chemistry of selective SIRT2 inhibitors is the discovery of a hydrophobic "selective pocket" in the structure of the SIRT2 (88). This discovery provided a rationale for the design of the selective SIRT2 inhibitors and many inhibitors exploiting the "selectivity pocket" have been described.

There are several groups of structurally diverse inhibitors which bind to the "selectivity pocket", confirmed by crystallographic analysis (Figure 11). One of the first discovered was the aminothiazole class of inhibitors (so called SirReals). SirReal2 (compound 34, Figure 11) was one of the most potent and selective inhibitors in this class (88). 2-((4,6-dimethylpyrimidin-2-yl)thio)acetamide motif of aminothiazole inhibitors interacts with "selectivity pocket" and its bioactive conformation was confirmed to acquire intramolecular hydrogen bonding (dashed lines - Figure 11). SirReal2 only partially occupied the substrate binding site, which inspired further development of 2-((4,6-dimethylpyrimidin-2-yl)thio)acetamide ligands, 35 using structure extension strategy in order to further exploit the substrate binding site $(89,90)$. The discovery of 2-((4,6-dimethylpyrimidin-2-yl)thio)acetamide motif inspired the design of azidothalidomide-conjugate proteolysis targeting chimera (PROTAC) inhibitor, 36, which could boost future biological studies on SIRT2 (91).

Besides 2-((4,6-dimethylpyrimidin-2-yl)thio)acetamide motif, there are several reports on other SIRT2 inhibitors which exploit the "selectivity pocket". One group of highly selective thienopyrimidinones, 37, was discovered using structure-based virtual screening, and characterized in terms of the binding mode through crystallographic studies (92). Another group of anilinobenzamides was also described to bind to a "selectivity pocket" (compound 38) (93). This group was further optimized into the mechanism-based inhibitor, 39, by exploiting substrate binding site which resulted in highly potent and selective inhibitor with antiproliferative activity in breast cancer cells and potent neurite outgrowth activity in neuro-2a (N2a) cells (94). Another example of inhibitor binding to the "selectivity pocket" is 40, identified through the high-throughput screen (95). Among mechanism-based inhibitors which occupy the "selectivity pocket" of SIRT2, thiomyristoyl compound $\mathbf{4 1}$ was thoughtfully tested in various human cancer cells and mouse models of breast cancer (96). The results indicated that $\mathbf{4 1}$ has broad anticancer effects and limited toxicity, qualifying this group of inhibitors as promising for future development. Related groups of potent, selective, stable in serum and watersoluble inhibitors have recently been reported (97). 


\section{Selective SIRT3 inhibitors}

A SIRT1 activator SRT1720 (compound 42, Figure 12) was one of the first reported SIRT3 inhibitors with significant potency and selectivity (98). An interesting strategy for developing SIRT3 peptide inhibitor, which implies the introduction of triphenylphosphonium moiety as a mitochondrial targeting moiety, was used to yield nonselective SIRT1-3 inhibitor with SIRT3 specific biological response (compound 43, Figure 12). This compound has shown comparable effects to less potent, but more SIRT3 selective cambinol analog 44 on the induction of autophagy and cell death in diffuse large B cell lymphomas (99).

Thiourea mechanism-based inhibitors, 45, derived from a group of inhibitors represented by $\mathbf{3 3}$, with significant selectivity towards SIRT3 were also described (100).

\section{Selective SIRT4 inhibitors}

SIRT4 has remained without a selective inhibitor until the moment of writing this review. With crystal structure and activity assays for SIRT4 emerging just recently, it is expected that the discovery of selective inhibitors will happen soon enough. Nicotinamide and suramin, as pan sirtuin inhibitors, were characterized on SIRT4 inhibition using currently developed assays. It was reported that SIRT4 is the most sensitive on nicotinamide inhibition among sirtuins, which could represent a good starting point for future fragment-based optimization campaigns $(101,102)$.

\section{Selective SIRT5 inhibitors}

Many selective and potent inhibitors of SIRT5 reported so far are in the class of a mechanism-based peptidomimetic inhibitors. One of the most promising inhibitors reported to date is thiourea-based 46 (Figure 12) (103). However, a recent study, using systematic shortening of available SIRT5 peptidomimetic inhibitors, suggested (S)-3-(2naphthylthio)succinylamide scaffold (47, Figure 12) as a useful starting point for the systematic development of small molecules that potently and selectively target SIRT5 structure (104). 


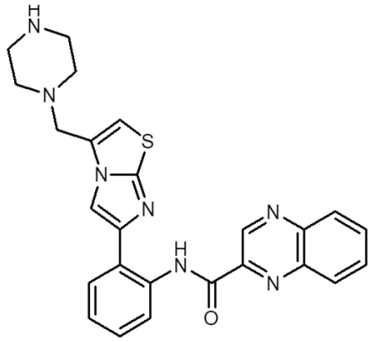

(42) SRT1720

SIRT3 $\left(\mathrm{IC}_{50}=0.85-\mu \mathrm{M}\right)$

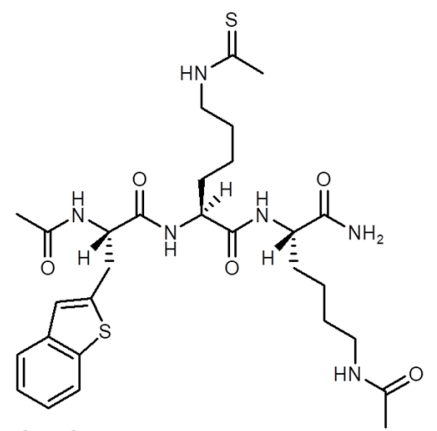

(45)

SIRT1 $\left(I C_{50}=14.43 \mu \mathrm{M}\right)$

SIRT2 $\left(I_{50}=15.5 \mu \mathrm{M}\right)$

SIRT3 $\left(\mathrm{IC}_{50}=1.44 \mu \mathrm{M}\right)$

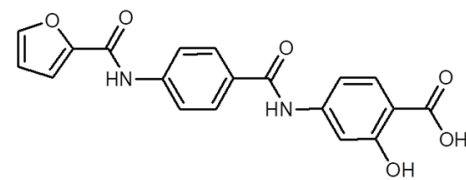

(48)

SIRT1 $\left(\mathrm{IC}_{50}=599 \mu \mathrm{M}\right)$

SIRT2 $\left(I_{50}=582 \mu \mathrm{M}\right)$

SIRT6 $\left(\mathrm{IC}_{50}=22 \mu \mathrm{M}\right)$

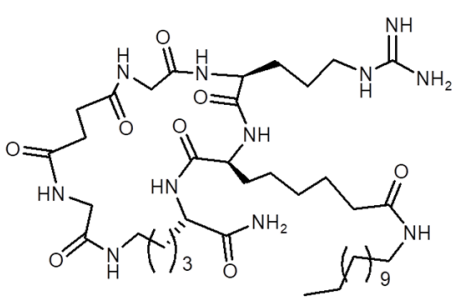

(51)

SIRT7 $\left(I C_{50}=5 \mu \mathrm{M}\right)$

SIRT1-3 (IC $\left.{ }_{50}=0.55-4.3 \mu \mathrm{M}\right)$

$\operatorname{SIRT5}\left(\mathrm{IC}_{50}=11 \mu \mathrm{M}\right)$

SIRT6 $\left(\mathrm{IC}_{50}>200 \mu \mathrm{M}\right)$

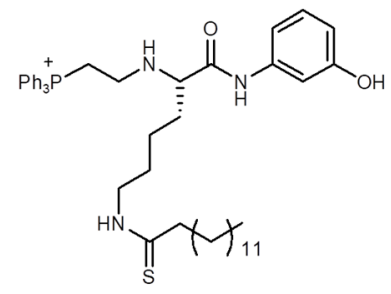

(43)

SIRT1 $\left(\mathrm{IC}_{50}=2.8 \mu \mathrm{M}\right)$

SIRT2 $\left(\right.$ IC $\left._{50}=0.062 \mu \mathrm{M}\right)$

SIRT3 $\left(I_{50}=0.53 \mu \mathrm{M}\right)$<smiles>O=C(O)CCNC(=S)NCCCCC(NS(=O)(=O)c1cccc(F)c1)C(=O)N[C@@H](Cc1c[nH]c2ccccc12)C(=O)NC1CCCC1</smiles>

(46)

SIRT1 (Inh<20\%@10 $\mu$ M)

SIRT2-3 (Inh < 10\% @ $10 \mu \mathrm{M})$

SIRT5 $\left(\mathrm{IC}_{50}=0.11 \mu \mathrm{M}\right)$

SIRT6 (Inh \% < 10\% @ $10 \mu \mathrm{M})$<smiles>CC(/C=C/C(=O)NO)=C\C(C)C(=O)c1ccc(N(C)C)cc1</smiles>

\section{(49) Trichostatin A}

HDAC1 $\left(I C_{50}=0.0015 \mu \mathrm{M}\right)$

HDAC3 $\left(I_{50}=0.0006 \mu \mathrm{M}\right)$

HDAC4 $\left(\mathrm{IC}_{50}=0.038 \mu \mathrm{M}\right)$

HDAC6 $\left(\mathrm{IC}_{50}=0.0086 \mu \mathrm{M}\right)$

HDAC8 $\left(\right.$ IC $\left._{50}=0.49 \mu \mathrm{M}\right)$

SIRT6 $\left(I_{50}=2.02-4.62 \mu \mathrm{M}\right)$

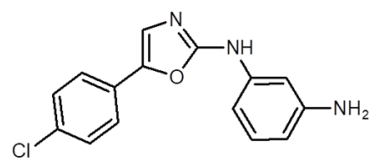

(52)

$\operatorname{SIRT7}\left(\mathrm{IC}_{50}=0.325 \mu \mathrm{M}\right)$<smiles>COc1cc2cc(-c3ccccc3)ccc2c(Cc2c(-c3ccc(C)cc3)[nH][nH]c2=O)c1O</smiles>

(44)

SIRT1 $\left(\mathrm{IC}_{50}=41 \mu \mathrm{M}\right)$

SIRT2 $\left(I_{50}=32 \mu \mathrm{M}\right)$

SIRT3 $\left(\mathrm{IC}_{50}=6 \mu \mathrm{M}\right)$

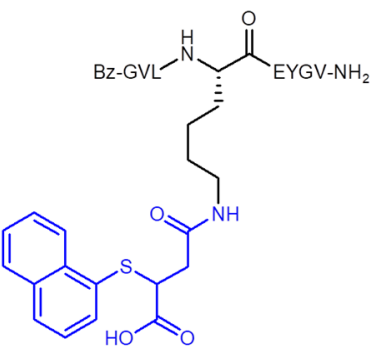

(47)

SIRT1-3 $\left(\right.$ IC $_{50}=$ n.i. $)$

SIRT5 $\left(I C_{50}=0.0154 \mu \mathrm{M}\right)$

SIRT6 (IC 50 n.i. $)$<smiles>[R]c1cc([C@H]2Oc3cc(O)cc(O)c3C[C@H]2OC(=O)c2cc(O)c(O)c(O)c2)cc(O)c1O</smiles>

$\mathrm{R}=\mathrm{H}$

SIRT6 $\left(\mathrm{IC}_{50}=2.5 \mu \mathrm{M}\right)$

(50b)

$\mathrm{R}=\mathrm{OH}$

SIRT6 $\left(\mathrm{IC}_{50}=5.4 \mu \mathrm{M}\right)$

Figure 12. Chemical structures of selective SIRT3-7 inhibitors

Slika 12. Hemijske strukture selektivnih SIRT3-7 inhibitora 


\section{Selective SIRT6 inhibitors}

Significant achievements have been made in SIRT6 inhibitors discovery over the past few years. Utilizing the crystal structure of SIRT6 in complex with adenosine diphosphate ribose as a starting point for in silico structure-based screening, Parenti et al. reported the first selective inhibitors of SIRT6, among which salicylate-based compounds was singled out as the most promising for future optimization (105). Further optimization of obtained salicylate-based compound resulted in compound 48 with improved potency and selectivity exhibited to sensitize pancreatic cancer cells to gemcitabine (Figure 12) (106).

Trichostatin A, 49 an inhibitor of HDACs from class I and II, was discovered to inhibit SIRT6, but not other SIRT isoforms. Although 49 inhibits HDACs through a zinc binding mechanism, the inhibition of SIRT 6 was unrelated to the coordination of the zinc which was validated by crystallographic studies. This is the first hydroxamic acid among sirtuin inhibitors reported so far (107).

Among natural products, quercetin derivatives catechin gallate (50a) and gallocatechin gallate $(\mathbf{5 0 b})$ were reported to be potent inhibitors of SIRT6. According to the recently reported crystal structure, catechin gallate occupies the same allosteric binding site on SIRT6 as SIRT6 activators $(108,109)$. Potent mechanism-based peptidomimetic inhibitors of SIRT6 were also described. Unfortunately, these inhibitors demonstrated a lack of selectivity (110).

\section{Selective SIRT7 inhibitors}

The first potent mechanism-based cyclic peptide SIRT7 inhibitors were reported just recently (51, Figure 12). However, they lack selectivity (111). At the same time, through in vitro enzymatic screening, a potent small molecule inhibitor of SIRT7 was reported (52, Figure 12). Despite reporting inhibition of cancer growth in vivo on a mice model of uterine sarcoma, the authors of the study didn't report selectivity of the inhibitor across sirtuin family (112). The crystal structure of SIRT7 has not yet been discovered, except $\mathrm{N}$-terminal fragment.

\section{HDAC inhibitors on the market}

Until the end of 2020, there had been four pan-HDAC inhibitors (demonstrating nonselective HDAC profile) approved by FDA and one approved HDAC inhibitor developed in China. Regarding their chemical nature (Figure 13), the approved HDACi can be classified as: a) Hydroxamic acid derivatives: Vorinostat $\left(\right.$ Zolinza $\left.^{\mathrm{TM}}\right)$, Belinostat (Beleodaq $^{\mathrm{TM}}$ ) and Panobinostat $\left(\right.$ Farydak $\left.^{\mathrm{TM}}\right)$, b) Disulfide based HDAC inhibitor: Romidepsin (Istodax ${ }^{\mathrm{TM}}$ ) and c) Benzamide HDACi: Chidamide (Epidaza ${ }^{\mathrm{TM}}$ ).

The clinically used HDAC inhibitors are licensed for hematological cancers, specifically in the therapy of T-cell lymphoma and multiple myeloma (113). 
A. Hydroxamic acid derivatives as HDAC inhibitors<smiles>O=C(CCCCCCC(=O)Nc1ccccc1)NO</smiles>

Vorinostat<smiles>O=C(/C=C/c1cccc(S(=O)(=O)Nc2ccccc2)c1)NO</smiles>

Belinostat

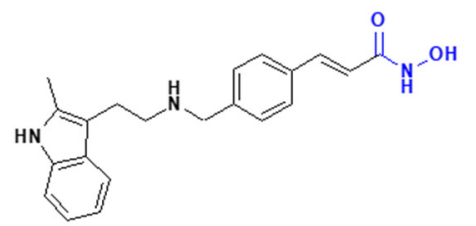

Panobinostat
B. Disulfide prodrug as HDAC inhibitor

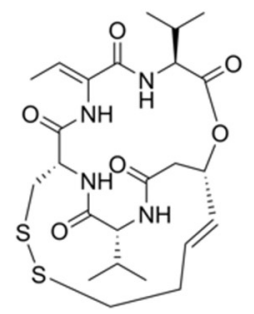

Romidepsin
C. Benzamide derivative as HDAC inhibitor<smiles>Nc1ccc(F)cc1NC(=O)c1ccc(CNC(=O)/C=C/c2cccnc2)cc1</smiles>

Chidamide

Figure 13. Chemical structures of approved HDAC inhibitors

Slika 13. Hemijske structure registrovanih HDAC inhibitora

\section{Conclusions}

It is of paramount importance to continue the research of histone deacetylase inhibitors in the medicinal chemistry. So far, the global oncology market has been introduced with five HDAC inhibitors, and none of the SIRT inhibitors. Though the great improvements in our understanding of the chemical biology of HDAC and SIRT inhibitors, the puzzle should be completed with several objectives:

a) The in vitro assays for HDAC and SIRT inhibitory profiles should be revalidated to assess other catalytic activities rather than deacetylation,

b) Nanomolar selective SIRT inhibitors are highly welcome to further probe NAD ${ }^{+}-$ dependent control of acetylome and

c) Design and synthesis of novel HDAC and SIRT inhibitors should be conducted with data on HDAC-protein and SIRT-protein crosstalk in cellular signaling.

\section{Acknowledgements}

The authors acknowledge the project of the Ministry of Science and Technological Development of the Republic of Serbia, Contract No. 451-03-9/2021-14/200161. 


\section{References}

1. Jenuwein T, Allis CD. Translating the Histone Code. Science. 2001 Aug 10;293(5532):1074-80.

2. Peterson CL, Laniel M-A. Histones and histone modifications. Curr Biol. 2004 Jul 27;14(14):R546-51.

3. Allis CD, Jenuwein T. The molecular hallmarks of epigenetic control. Nat Rev Genet. 2016 Aug; 17(8):487-500.

4. Rousseaux S, Khochbin S. Histone Acylation beyond Acetylation: Terra Incognita in Chromatin Biology. Cell J. 2015;17(1):1-6.

5. LeRoy G, DiMaggio PA, Chan EY, Zee BM, Blanco MA, Bryant B, et al. A quantitative atlas of histone modification signatures from human cancer cells. Epigenetics Chromatin. 2013 Jul 5;6(1):20.

6. Willcockson MA, Healton SE, Weiss CN, Bartholdy BA, Botbol Y, Mishra LN, et al. H1 histones control the epigenetic landscape by local chromatin compaction. Nature. 2021 Jan;589(7841):293-8.

7. Xu Y, Zhang S, Lin S, Guo Y, Deng W, Zhang Y, et al. WERAM: a database of writers, erasers and readers of histone acetylation and methylation in eukaryotes. Nucleic Acids Res. 2017 Jan 4;45(D1):D264-70.

8. Bradbury CA, Khanim FL, Hayden R, Bunce CM, White DA, Drayson MT, et al. Histone deacetylases in acute myeloid leukaemia show a distinctive pattern of expression that changes selectively in response to deacetylase inhibitors. Leukemia. 2005 Oct;19(10):1751-9.

9. Zucchetti B, Shimada AK, Katz A, Curigliano G. The role of histone deacetylase inhibitors in metastatic breast cancer. The Breast. 2019 Feb 1;43:130-4.

10. Grozinger CM, Hassig CA, Schreiber SL. Three proteins define a class of human histone deacetylases related to yeast Hda1p. Proc Natl Acad Sci. 1999 Apr 27;96(9):4868-73.

11. Yang X-J, Grégoire S. Class II Histone Deacetylases: from Sequence to Function, Regulation, and Clinical Implication. Mol Cell Biol. 2005 Apr 15;25(8):2873-84.

12. Rajan A, Shi H, Xue B. Class I and II Histone Deacetylase Inhibitors Differentially Regulate Thermogenic Gene Expression in Brown Adipocytes. Sci Rep. 2018 Aug 30;8(1):13072.

13. Wang G, He J, Zhao J, Yun W, Xie C, Taub JW, et al. Class I and Class II Histone Deacetylases Are Potential Therapeutic Targets for Treating Pancreatic Cancer. PLOS ONE. 2012 Dec 14;7(12):e52095.

14. Imai S, Armstrong CM, Kaeberlein M, Guarente L. Transcriptional silencing and longevity protein Sir2 is an NAD-dependent histone deacetylase. Nature. 2000 Feb;403(6771):795-800.

15. Gao L, Cueto MA, Asselbergs F, Atadja P. Cloning and Functional Characterization of HDAC11, a Novel Member of the Human Histone Deacetylase Family*. J Biol Chem. 2002 Jul 12;277(28):25748-55.

16. Aramsangtienchai P, Spiegelman NA, He B, Miller SP, Dai L, Zhao Y, et al. HDAC8 Catalyzes the Hydrolysis of Long Chain Fatty Acyl Lysine. ACS Chem Biol. 2016 Oct 21;11(10):2685-92.

17. Mihaylova MM, Shaw RJ. Metabolic reprogramming by class I and II histone deacetylases. Trends Endocrinol Metab TEM. 2013 Jan;24(1):48-57.

18. Bolden JE, Shi W, Jankowski K, Kan C-Y, Cluse L, Martin BP, et al. HDAC inhibitors induce tumorcell-selective pro-apoptotic transcriptional responses. Cell Death Dis. 2013 Feb;4(2):e519-e519.

19. Chao M-W, Chang L-H, Tu H-J, Chang C-D, Lai M-J, Chen Y-Y, et al. Combination treatment strategy for pancreatic cancer involving the novel HDAC inhibitor MPT0E028 with a MEK inhibitor beyond K-Ras status. Clin Epigenetics. 2019 May 29;11(1):85. 
20. Finnin MS, Donigian JR, Cohen A, Richon VM, Rifkind RA, Marks PA, et al. Structures of a histone deacetylase homologue bound to the TSA and SAHA inhibitors. Nature. 1999 Sep;401(6749):188-93.

21. Wang D-F, Wiest O, Helquist P, Lan-Hargest H-Y, Wiech NL. On the function of the 14 A long internal cavity of histone deacetylase-like protein: implications for the design of histone deacetylase inhibitors. J Med Chem. 2004 Jun 17;47(13):3409-17.

22. Lucy Gantt SM, Decroos C, Lee MS, Gullett LE, Bowman CM, Christianson DW, et al. General Base-General Acid Catalysis in Human Histone Deacetylase 8. Biochemistry. 2016 Feb 9;55(5):820-32.

23. Sauve AA, Youn DY. Sirtuins: NAD+-dependent deacetylase mechanism and regulation. Curr Opin Chem Biol. 2012 Dec 1;16(5):535-43.

24. Friend C, Scher W, Holland JG, Sato T. Hemoglobin Synthesis in Murine Virus-Induced Leukemic Cells In Vitro: Stimulation of Erythroid Differentiation by Dimethyl Sulfoxide. Proc Natl Acad Sci. 1971 Feb 1;68(2):378-82.

25. Breslow R, Jursic B, Yan ZF, Friedman E, Leng L, Ngo L, et al. Potent cytodifferentiating agents related to hexamethylenebisacetamide. Proc Natl Acad Sci. 1991 Jul 1;88(13):5542-6.

26. Bedalov A, Gatbonton T, Irvine WP, Gottschling DE, Simon JA. Identification of a small molecule inhibitor of Sir2p. Proc Natl Acad Sci. 2001 Dec 18;98(26):15113-8.

27. Zhou Z, Ma T, Zhu Q, Xu Y, Zha X. Recent advances in inhibitors of sirtuin1/2: an update and perspective. Future Med Chem. 2018 Apr 1;10(8):907-34.

28. Rajabi N, Galleano I, Madsen AS, Olsen CA. Targeting Sirtuins: Substrate Specificity and Inhibitor Design. Prog Mol Biol Transl Sci. 2018;154:25-69.

29. Cunliffe VT. Eloquent silence: developmental functions of Class I histone deacetylases. Curr Opin Genet Dev. 2008 Oct 1;18(5):404-10.

30. Liu J, Kelly J, Yu W, Clausen D, Yu Y, Kim H, et al. Selective Class I HDAC Inhibitors Based on Aryl Ketone Zinc Binding Induce HIV-1 Protein for Clearance. ACS Med Chem Lett. 2020 Jul 9;11(7):1476-83.

31. Taplick J, Kurtev V, Kroboth K, Posch M, Lechner T, Seiser C. Homo-oligomerisation and nuclear localisation of mouse histone deacetylase 1. J Mol Biol. 2001 Apr 20;308(1):27-38.

32. Liu J, Yu Y, Kelly J, Sha D, Alhassan A-B, Yu W, et al. Discovery of Highly Selective and Potent HDAC3 Inhibitors Based on a 2-Substituted Benzamide Zinc Binding Group. ACS Med Chem Lett. 2020 Dec 10;11(12):2476-83.

33. Somoza JR, Skene RJ, Katz BA, Mol C, Ho JD, Jennings AJ, et al. Structural Snapshots of Human HDAC8 Provide Insights into the Class I Histone Deacetylases. Structure. 2004 Jul 1;12(7):1325-34.

34. Maolanon AR, Madsen AS, Olsen CA. Innovative Strategies for Selective Inhibition of Histone Deacetylases. Cell Chem Biol. 2016 Jul 21;23(7):759-68.

35. KrennHrubec K, Marshall BL, Hedglin M, Verdin E, Ulrich SM. Design and evaluation of 'Linkerless' hydroxamic acids as selective HDAC8 inhibitors. Bioorg Med Chem Lett. 2007 May 15;17(10):2874-8.

36. Olson DE, Wagner FF, Kaya T, Gale JP, Aidoud N, Davoine EL, et al. Discovery of the first histone deacetylase 6/8 dual inhibitors. J Med Chem. 2013 Jun 13;56(11):4816-20.

37. Ingham OJ, Paranal RM, Smith WB, Escobar RA, Yueh H, Snyder T, et al. Development of a Potent and Selective HDAC8 Inhibitor. ACS Med Chem Lett. 2016 Oct 13;7(10):929-32. 
38. Hassan MM, Israelian J, Nawar N, Ganda G, Manaswiyoungkul P, Raouf YS, et al. Characterization of Conformationally Constrained Benzanilide Scaffolds for Potent and Selective HDAC8 Targeting. J Med Chem. 2020 Aug 13;63(15):8634-48.

39. Zhao C, Zang J, Ding Q, Inks ES, Xu W, Chou CJ, et al. Discovery of meta-sulfamoyl Nhydroxybenzamides as HDAC8 selective inhibitors. Eur J Med Chem. 2018 Apr 25;150:282-91.

40. Heimburg T, Kolbinger FR, Zeyen P, Ghazy E, Herp D, Schmidtkunz K, et al. Structure-Based Design and Biological Characterization of Selective Histone Deacetylase 8 (HDAC8) Inhibitors with Anti-Neuroblastoma Activity. J Med Chem. 2017 Dec 28;60(24):10188-204.

41. Marek M, Shaik TB, Heimburg T, Chakrabarti A, Lancelot J, Ramos-Morales E, et al. Characterization of Histone Deacetylase 8 (HDAC8) Selective Inhibition Reveals Specific Active Site Structural and Functional Determinants. J Med Chem. 2018 Nov 21;61(22):10000-16.

42. Taha TY, Aboukhatwa SM, Knopp RC, Ikegaki N, Abdelkarim H, Neerasa J, et al. Design, Synthesis, and Biological Evaluation of Tetrahydroisoquinoline-Based Histone Deacetylase 8 Selective Inhibitors. ACS Med Chem Lett. 2017 Aug 10;8(8):824-9.

43. Balasubramanian S, Ramos J, Luo W, Sirisawad M, Verner E, Buggy JJ. A novel histone deacetylase 8 (HDAC8)-specific inhibitor PCI-34051 induces apoptosis in T-cell lymphomas. Leukemia. 2008 May;22(5):1026-34.

44. Suzuki T, Ota Y, Ri M, Bando M, Gotoh A, Itoh Y, et al. Rapid Discovery of Highly Potent and Selective Inhibitors of Histone Deacetylase 8 Using Click Chemistry to Generate Candidate Libraries. J Med Chem. 2012 Nov 26;55(22):9562-75.

45. Lahm A, Paolini C, Pallaoro M, Nardi MC, Jones P, Neddermann P, et al. Unraveling the hidden catalytic activity of vertebrate class IIa histone deacetylases. Proc Natl Acad Sci. 2007 Oct 30;104(44):17335-40.

46. Luo L, Martin SC, Parkington J, Cadena SM, Zhu J, Ibebunjo C, et al. HDAC4 Controls Muscle Homeostasis through Deacetylation of Myosin Heavy Chain, PGC-1 $\alpha$, and Hsc70. Cell Rep. 2019 Oct 15;29(3):749-763.e12.

47. McGee SL, van Denderen BJW, Howlett KF, Mollica J, Schertzer JD, Kemp BE, et al. AMPactivated protein kinase regulates GLUT4 transcription by phosphorylating histone deacetylase 5. Diabetes. 2008 Apr;57(4):860-7.

48. Mielcarek M, Landles C, Weiss A, Bradaia A, Seredenina T, Inuabasi L, et al. HDAC4 Reduction: A Novel Therapeutic Strategy to Target Cytoplasmic Huntingtin and Ameliorate Neurodegeneration. PLOS Biol. 2013 Nov 26;11(11):e1001717.

49. Travers JG, Hu T, McKinsey TA. The black sheep of class IIa: HDAC7 SIKens the heart. J Clin Invest. 2020 Jun 1;130(6):2811-3.

50. Lobera M, Madauss KP, Pohlhaus DT, Wright QG, Trocha M, Schmidt DR, et al. Selective class IIa histone deacetylase inhibition via a nonchelating zinc-binding group. Nat Chem Biol. 2013 May;9(5):319-25.

51. Shinsky SA, Christianson DW. Polyamine Deacetylase Structure and Catalysis: Prokaryotic Acetylpolyamine Amidohydrolase and Eukaryotic HDAC10. Biochemistry. 2018 Jun 5;57(22):3105-14. 
52. Skultetyova L, Ustinova K, Kutil Z, Novakova Z, Pavlicek J, Mikesova J, et al. Human histone deacetylase 6 shows strong preference for tubulin dimers over assembled microtubules. Sci Rep. 2017 Sep 14;7(1):11547.

53. Hai Y, Christianson DW. Histone deacetylase 6 structure and molecular basis of catalysis and inhibition. Nat Chem Biol. 2016 Sep;12(9):741-7.

54. Hai Y, Shinsky SA, Porter NJ, Christianson DW. Histone deacetylase 10 structure and molecular function as a polyamine deacetylase. Nat Commun. 2017 May 18;8(1):15368.

55. Porter NJ, Mahendran A, Breslow R, Christianson DW. Unusual zinc-binding mode of HDAC6selective hydroxamate inhibitors. Proc Natl Acad Sci. 2017 Dec 19;114(51):13459-64.

56. Ruzic D, Petkovic M, Agbaba D, Ganesan A, Nikolic K. Combined Ligand and Fragment-based Drug Design of Selective Histone Deacetylase - 6 Inhibitors. Mol Inform. 2019;38(5):1800083.

57. Avelar LAA, Ruzic D, Djokovic N, Kurz T, Nikolic K. Structure-based design of selective histone deacetylase 6 zinc binding groups. J Biomol Struct Dyn. 2020 Jul 23;38(11):3166-77.

58. Bouchet S, Linot C, Ruzic D, Agbaba D, Fouchaq B, Roche J, et al. Extending Cross Metathesis To Identify Selective HDAC Inhibitors: Synthesis, Biological Activities, and Modeling. ACS Med Chem Lett. 2019 Jun 13;10(6):863-8.

59. Sun X, Xie Y, Sun X, Yao Y, Li H, Li Z, et al. The selective HDAC6 inhibitor Nexturastat A induces apoptosis, overcomes drug resistance and inhibits tumor growth in multiple myeloma. Biosci Rep. 2019 Mar 22;39(3):BSR20181916.

60. Patil V, Sodji QH, Kornacki JR, Mrksich M, Oyelere AK. 3-Hydroxypyridin-2-thione as novel zinc binding group for selective histone deacetylase inhibition. J Med Chem. 2013 May 9;56(9):3492-506.

61. Porter NJ, Wagner FF, Christianson DW. Entropy as a Driver of Selectivity for Inhibitor Binding to Histone Deacetylase 6. Biochemistry. 2018 Jul 3;57(26):3916-24.

62. Géraldy M, Morgen M, Sehr P, Steimbach RR, Moi D, Ridinger J, et al. Selective Inhibition of Histone Deacetylase 10: Hydrogen Bonding to the Gatekeeper Residue is Implicated. J Med Chem. 2019 May 9;62(9):4426-43.

63. Butler KV, Kalin J, Brochier C, Vistoli G, Langley B, Kozikowski AP. Rational design and simple chemistry yield a superior, neuroprotective HDAC6 inhibitor, tubastatin A. J Am Chem Soc. 2010 Aug 11;132(31):10842-6.

64. Herbst-Gervasoni CJ, Christianson DW. Binding of N8-Acetylspermidine Analogues to Histone Deacetylase 10 Reveals Molecular Strategies for Blocking Polyamine Deacetylation. Biochemistry. 2019 Dec 10;58(49):4957-69.

65. Cao J, Sun L, Aramsangtienchai P, Spiegelman NA, Zhang X, Huang W, et al. HDAC11 regulates type I interferon signaling through defatty-acylation of SHMT2. Proc Natl Acad Sci. 2019 Mar 19;116(12):5487-92.

66. Liu S-S, Wu F, Jin Y-M, Chang W-Q, Xu T-M. HDAC11: a rising star in epigenetics. Biomed Pharmacother. 2020 Nov 1;131:110607.

67. Son SI, Su D, Ho TT, Lin H. Garcinol Is an HDAC11 Inhibitor. ACS Chem Biol. 2020 Nov 20;15(11):2866-71.

68. Bora-Singhal N, Mohankumar D, Saha B, Colin CM, Lee JY, Martin MW, et al. Novel HDAC11 inhibitors suppress lung adenocarcinoma stem cell self-renewal and overcome drug resistance by suppressing Sox2. Sci Rep. 2020 Mar 13;10(1):4722. 
69. Son SI, Cao J, Zhu C-L, Miller SP, Lin H. Activity-Guided Design of HDAC11-Specific Inhibitors. ACS Chem Biol. 2019 Jul 19;14(7):1393-7.

70. Carafa V, Rotili D, Forgione M, Cuomo F, Serretiello E, Hailu GS, et al. Sirtuin functions and modulation: from chemistry to the clinic. Clin Epigenetics. 2016 May 25;8(1):61.

71. Parenti MD, Bruzzone S, Nencioni A, Del Rio A. Selectivity hot-spots of sirtuin catalytic cores. Mol Biosyst. 2015;11(8):2263-72.

72. Grozinger CM, Chao ED, Blackwell HE, Moazed D, Schreiber SL. Identification of a class of small molecule inhibitors of the sirtuin family of NAD-dependent deacetylases by phenotypic screening. J Biol Chem. 2001 Oct 19;276(42):38837-43.

73. Heltweg B, Gatbonton T, Schuler AD, Posakony J, Li H, Goehle S, et al. Antitumor Activity of a Small-Molecule Inhibitor of Human Silent Information Regulator 2 Enzymes. Cancer Res. 2006 Apr 15;66(8):4368-77.

74. Lara E, Mai A, Calvanese V, Altucci L, Lopez-Nieva P, Martinez-Chantar ML, et al. Salermide, a Sirtuin inhibitor with a strong cancer-specific proapoptotic effect. Oncogene. 2009 Feb;28(6):781-91.

75. Uciechowska U, Schemies J, Neugebauer RC, Huda E-M, Schmitt ML, Meier R, et al. Thiobarbiturates as Sirtuin Inhibitors: Virtual Screening, Free-Energy Calculations, and Biological Testing. ChemMedChem. 2008;3(12):1965-76.

76. McCarthy AR, Pirrie L, Hollick JJ, Ronseaux S, Campbell J, Higgins M, et al. Synthesis and biological characterisation of sirtuin inhibitors based on the tenovins. Bioorg Med Chem. 2012 Mar 1;20(5):1779-93.

77. Yuan H, Wang Z, Li L, Zhang H, Modi H, Horne D, et al. Activation of stress response gene SIRT1 by BCR-ABL promotes leukemogenesis. Blood. 2012 Feb 23;119(8):1904-14.

78. Mellini P, Kokkola T, Suuronen T, Salo HS, Tolvanen L, Mai A, et al. Screen of pseudopeptidic inhibitors of human sirtuins 1-3: two lead compounds with antiproliferative effects in cancer cells. J Med Chem. 2013 Sep 12;56(17):6681-95.

79. Disch JS, Evindar G, Chiu CH, Blum CA, Dai H, Jin L, et al. Discovery of thieno[3,2-d]pyrimidine6-carboxamides as potent inhibitors of SIRT1, SIRT2, and SIRT3. J Med Chem. 2013 May 9;56(9):3666-79.

80. Karaman B, Alhalabi Z, Swyter S, Mihigo SO, Andrae-Marobela K, Jung M, et al. Identification of Bichalcones as Sirtuin Inhibitors by Virtual Screening and In Vitro Testing. Molecules. 2018 Feb;23(2):416.

81. Yeong KY, Khaw KY, Takahashi Y, Itoh Y, Murugaiyah V, Suzuki T. Discovery of gammamangostin from Garcinia mangostana as a potent and selective natural SIRT2 inhibitor. Bioorganic Chem. 2020 Jan 1;94:103403.

82. Gey C, Kyrylenko S, Hennig L, Nguyen L-HD, Büttner A, Pham HD, et al. Phloroglucinol Derivatives Guttiferone G, Aristoforin, and Hyperforin: Inhibitors of Human Sirtuins SIRT1 and SIRT2. Angew Chem Int Ed. 2007;46(27):5219-22.

83. Süssmuth SD, Haider S, Landwehrmeyer GB, Farmer R, Frost C, Tripepi G, et al. An exploratory double-blind, randomized clinical trial with selisistat, a SirT1 inhibitor, in patients with Huntington's disease. Br J Clin Pharmacol. 2015 Mar;79(3):465-76.

84. Napper AD, Hixon J, McDonagh T, Keavey K, Pons J-F, Barker J, et al. Discovery of indoles as potent and selective inhibitors of the deacetylase SIRT1. J Med Chem. 2005 Dec 15;48(25):8045-54. 
85. Gertz M, Fischer F, Nguyen GTT, Lakshminarasimhan M, Schutkowski M, Weyand M, et al. Ex527 inhibits Sirtuins by exploiting their unique NAD+-dependent deacetylation mechanism. Proc Natl Acad Sci. 2013 Jul 23;110(30):E2772-81.

86. Sanders BD, Jackson B, Brent M, Taylor AM, Dang W, Berger SL, et al. Identification and characterization of novel sirtuin inhibitor scaffolds. Bioorg Med Chem. 2009 Oct 1;17(19):7031-41.

87. Wang J, Zang W, Liu J, Zheng W. Bivalent SIRT1 inhibitors. Bioorg Med Chem Lett. 2017 Jan 15;27(2):180-6.

88. Rumpf T, Schiedel M, Karaman B, Roessler C, North BJ, Lehotzky A, et al. Selective Sirt2 inhibition by ligand-induced rearrangement of the active site. Nat Commun. 2015 Feb 12;6(1):6263.

89. Yang L-L, Xu W, Yan J, Su H-L, Yuan C, Li C, et al. Crystallographic and SAR analyses reveal the high requirements needed to selectively and potently inhibit SIRT2 deacetylase and decanoylase. MedChemComm. 2019 Jan 23;10(1):164-8.

90. Yang L-L, Wang H-L, Zhong L, Yuan C, Liu S-Y, Yu Z-J, et al. X-ray crystal structure guided discovery of new selective, substrate-mimicking sirtuin 2 inhibitors that exhibit activities against non-small cell lung cancer cells. Eur J Med Chem. 2018 Jul 15;155:806-23.

91. Schiedel M, Herp D, Hammelmann S, Swyter S, Lehotzky A, Robaa D, et al. Chemically Induced Degradation of Sirtuin 2 (Sirt2) by a Proteolysis Targeting Chimera (PROTAC) Based on Sirtuin Rearranging Ligands (SirReals). J Med Chem. 2018 Jan 25;61(2):482-91.

92. Sundriyal S, Moniot S, Mahmud Z, Yao S, Di Fruscia P, Reynolds CR, et al. Thienopyrimidinone Based Sirtuin-2 (SIRT2)-Selective Inhibitors Bind in the Ligand Induced Selectivity Pocket. J Med Chem. 2017 Mar 9;60(5):1928-45.

93. Suzuki T, Khan MN, Sawada H, Imai E, Itoh Y, Yamatsuta K, et al. Design, synthesis, and biological activity of a novel series of human sirtuin-2-selective inhibitors. J Med Chem. 2012 Jun 28;55(12):5760-73.

94. Mellini P, Itoh Y, Tsumoto H, Li Y, Suzuki M, Tokuda N, et al. Potent mechanism-based sirtuin-2selective inhibition by an in situ-generated occupant of the substrate-binding site, "selectivity pocket" and NAD+-binding site. Chem Sci. 2017 Aug 21;8(9):6400-8.

95. Kudo N, Ito A, Arata M, Nakata A, Yoshida M. Identification of a novel small molecule that inhibits deacetylase but not defatty-acylase reaction catalysed by SIRT2. Philos Trans R Soc B Biol Sci. 2018 Jun 5;373(1748):20170070.

96. Jing H, Hu J, He B, Negron Abril YL, Stupinski J, Weiser K, et al. A SIRT2-selective inhibitor promotes c-Myc oncoprotein degradation and exhibits broad anticancer activity. Cancer Cell. 2016 Mar 14;29(3):297-310.

97. Nielsen AL, Rajabi N, Kudo N, Lundø K, Moreno-Yruela C, Bæk M, et al. Mechanism-based inhibitors of SIRT2: structure-activity relationship, X-ray structures, target engagement, regulation of $\alpha$-tubulin acetylation and inhibition of breast cancer cell migration. RSC Chem Biol [Internet]. 2021 Jan 14 [cited 2021 Jan 26]. Available from: https://pubs.rsc.org/en/content/articlelanding/2021/cb/d0cb00036a

98. Nguyen GTT, Schaefer S, Gertz M, Weyand M, Steegborn C. Structures of human sirtuin 3 complexes with ADP-ribose and with carba-NAD+ and SRT1720: binding details and inhibition mechanism. Acta Crystallogr D Biol Crystallogr. 2013 Aug;69(Pt 8):1423-32. 
99. Li M, Chiang Y-L, Lyssiotis CA, Teater MR, Hong JY, Shen H, et al. Non-oncogene Addiction to SIRT3 Plays a Critical Role in Lymphomagenesis. Cancer Cell. 2019 Jun 10;35(6):916-931.e9.

100. Chen B, Wang J, Huang Y, Zheng W. Human SIRT3 tripeptidic inhibitors containing N(ع)thioacetyl-lysine. Bioorg Med Chem Lett. 2015 Sep 1;25(17):3481-7.

101. Pannek M, Simic Z, Fuszard M, Meleshin M, Rotili D, Mai A, et al. Crystal structures of the mitochondrial deacylase Sirtuin 4 reveal isoform-specific acyl recognition and regulation features. Nat Commun. 2017 Nov 15;8(1):1513.

102. Li Y, Zhao Y, Cao Z, Wang J, Liu T, Li Y, et al. Development of a mitochondrial sirtuin 4 FRET assay based on its activity for removing 3-hydroxy-3-methylglutaryl (HMG) modification. RSC Adv. 2021 Jan 11;11(5):2677-81.

103. Rajabi N, Auth M, Troelsen KR, Pannek M, Bhatt DP, Fontenas M, et al. Mechanism-based Inhibitors of the Human Sirtuin 5 Deacylase: Structure-Activity Relationship, Biostructural, and Kinetic Insight. Angew Chem Int Ed Engl. 2017 Nov 20;56(47):14836-41.

104. Kalbas D, Liebscher S, Nowak T, Meleshin M, Pannek M, Popp C, et al. Potent and Selective Inhibitors of Human Sirtuin 5. J Med Chem. 2018 Mar 22;61(6):2460-71.

105. Parenti MD, Grozio A, Bauer I, Galeno L, Damonte P, Millo E, et al. Discovery of novel and selective SIRT6 inhibitors. J Med Chem. 2014 Jun 12;57(11):4796-804.

106. Damonte P, Sociali G, Parenti MD, Soncini D, Bauer I, Boero S, et al. SIRT6 inhibitors with salicylate-like structure show immunosuppressive and chemosensitizing effects. Bioorg Med Chem. 2017 Oct 15;25(20):5849-58.

107. You W, Steegborn C. Structural Basis of Sirtuin 6 Inhibition by the Hydroxamate Trichostatin A: Implications for Protein Deacylase Drug Development. J Med Chem. 2018 Dec 13;61(23):10922-8.

108. Rahnasto-Rilla M, Tyni J, Huovinen M, Jarho E, Kulikowicz T, Ravichandran S, et al. Natural polyphenols as sirtuin 6 modulators. Sci Rep. 2018 Mar 7;8(1):4163.

109. You W, Zheng W, Weiss S, Chua KF, Steegborn C. Structural basis for the activation and inhibition of Sirtuin 6 by quercetin and its derivatives. Sci Rep. 2019 Dec 16;9(1):19176.

110. He B, Hu J, Zhang X, Lin H. Thiomyristoyl Peptides as Cell-Permeable Sirt6 Inhibitors. Org Biomol Chem. 2014 Oct 14;12(38):7498.

111. Li S, Wu B, Zheng W. Cyclic tripeptide-based potent human SIRT7 inhibitors. Bioorg Med Chem Lett. 2019 Feb 1;29(3):461-5.

112. Kim J-H, Kim D, Cho SJ, Jung K-Y, Kim J-H, Lee JM, et al. Identification of a novel SIRT7 inhibitor as anticancer drug candidate. Biochem Biophys Res Commun. 2019 Jan 8;508(2):451-7.

113. Chen I-C, Sethy B, Liou J-P. Recent Update of HDAC Inhibitors in Lymphoma. Front Cell Dev Biol. 2020;8:576391. 


\section{Medicinska hemija inhibitora histon deacetilaza}

\section{Dušan Ružić ${ }^{\#}$, Nemanja Djoković ${ }^{\#}$, Katarina Nikolić i Zorica Vujić*}

Univerzitet u Beogradu - Farmaceutski fakultet, Katedra za farmaceutsku hemiju, Vojvode Stepe 450, 11221 Beograd, Srbija

*Autor za korespondenciju: Prof. dr Zorica Vujic, E-mail: zvujic@pharmacy.bg.ac.rs

\# autori su podjednako doprineli radu

\section{Kratak sadržaj}

Savremena hemoterapija kancera se bazira na velikom broju različitih naučnih pristupa. Dugo se smatralo da bi genetsku nestabilnost u kancerskim oboljenjima trebalo lečiti agensima koji direktno oštećuju DNK. Razumevanje molekularnih osnova malignih oboljenja rasvetlilo je značaj fenotipske plastičnosti. U eri epigenetike, učinjeni su mnogi napori da se izmeni aberantna homeostaza u kancerskom oboljenju bez modifikovanja sekvence DNK. Jedna od takvih strategija je modulacija lizinskog acetiloma u humanim kancerima. Da bi se acetil grupa uklonila sa histona, ćelije koriste enzime histon deacetilaze. Poremećena ravnoteža acetilacije i deacetilacije na lizinskim ostacima histona može biti regulisana inhibitorima histon deacetilaza.

Kroz ovaj pregledni rad, biće prikazani mehanizmi inhibicije izoformi histon deacetilaza, različiti inhibitori histon deacetilaza, kao i njihove terapijske primene i očekivanja u modernom razvoju lekova.

Ključne reči: histon deacetilaze, sirtuini, inhibitori, epigenetika, acetilom 